\title{
Efficacy and Safety of Intravenous Valproate for Status Epilepticus: A Systematic Review
}

\author{
Eugen Trinka $\cdot$ Julia Höfler $\cdot$ Alexander Zerbs • \\ Francesco Brigo
}

Published online: 8 May 2014

(c) The Author(s) 2014. This article is published with open access at Springerlink.com

\begin{abstract}
Introduction The effectiveness of valproate (VPA) in the treatment of focal and generalized epilepsies is well established. The drug has a wide spectrum of action, good tolerability, and has been available as an injectable formulation since 1993. Despite the lack of class A evidence, it has been used extensively in various forms of status epilepticus (SE).

Aim Our aim was to present a systematic review of data from randomized and non-randomized controlled trials to evaluate the efficacy and safety of intravenous VPA for the treatment of SE.

Methods Data sources included MEDLINE, back tracing of references in pertinent studies, and contact with the manufacturer of VPA (Sanofi-Aventis).
\end{abstract}

\section{E. Trinka $(\bowtie) \cdot$ J. Höfler $\cdot$ A. Zerbs}

Department of Neurology, Christian Doppler Klinik, Centre for

Cognitive Neuroscience Salzburg, Paracelsus Medical

University Salzburg, Ignaz Harrerstrasse 79, 5020 Salzburg,

Austria

e-mail: e.trinka@salk.at

E. Trinka $\cdot$ J. Höfler $\cdot$ A. Zerbs

Christian Doppler Medical Centre, Salzburg, Austria

E. Trinka

Centre for Cognitive Neurosciences Salzburg, Salzburg, Austria

E. Trinka

University for Medical Informatics and Health Technology, UMIT, Hall in Tirol, Austria

\section{F. Brigo}

Department of Neurological and Movement Sciences,

University of Verona, Verona, Italy
Results Overall, the search strategy yielded 433 results (425 MEDLINE, seven congress abstracts, one unpublished study); after excluding duplicate publications and case reports, 30 studies were identified (the earliest was published in 1993, the most recent in 2012); ten were controlled (six randomized controlled trials, four non-randomized controlled studies), and 20 uncontrolled trials (eight prospective observational studies, 12 retrospective case series). The cumulative literature describes the experiences of 860 patients with various forms of SE treated with intravenous VPA. The overall response rate to abrogate SE was $70.9 \%(601 / 848 ; 95 \%$ confidence interval [CI] 67.8-73.9). Response rates to intravenous VPA were better in children than in adults and did not differ between the SE types. The most commonly reported effective doses were between 15 and $45 \mathrm{mg} / \mathrm{kg}$ in bolus $(6 \mathrm{mg} / \mathrm{kg} / \mathrm{min})$ followed by $1-3 \mathrm{mg} / \mathrm{kg} / \mathrm{h}$ infusion. Safety studies of intravenous VPA administration in patients with SE showed a low incidence of adverse events overall $(<10 \%)$, mainly dizziness, thrombocytopenia, and mild hypotension, which was independent of infusion rates. Of note, good cardiovascular and respiratory tolerability was observed in these studies, even at high doses and fast infusion rates (up to $30 \mathrm{mg} / \mathrm{kg}$ at $10 \mathrm{mg} / \mathrm{kg} / \mathrm{min}$ ), despite multiple morbidities or other antiepileptic drugs. The most serious concern relates to the possibility of acute encephalopathy, sometimes related to hepatic abnormalities or hyperammonemia.

Conclusions The published experience is consistent with VPA being a safe and effective therapeutic option for patients with established SE who have previously failed conventional first-line treatment with benzodiazepines, but high-quality randomized controlled trials are needed to inform clinicians on its comparative effectiveness in SE. 


\section{Key Points}

The overall response rate to abrogate status epilepticus (SE) with intravenous (IV) valproate was $70.9 \%$ (601 out of 848 patients; $95 \%$ confidence interval [CI] 67.8-73.9), with a most commonly used dose between 15 and $45 \mathrm{mg} / \mathrm{kg}$ in bolus $(6 \mathrm{mg} / \mathrm{kg} /$ $\mathrm{min}$ ) followed by $1-3 \mathrm{mg} / \mathrm{kg} / \mathrm{h}$ infusion.

The incidence of adverse events was low overall $(<10 \%)$, mainly dizziness, thrombocytopenia, and mild hypotension, which was independent of infusion rates, and a good cardiovascular and respiratory tolerability even in high doses and fast infusion rates up to $30 \mathrm{mg} / \mathrm{kg}$ at $10 \mathrm{mg} / \mathrm{kg} / \mathrm{min}$.

Given the low incidence of clinically relevant adverse events, and the potentially serious or even fatal consequences of not abrogating seizure activity rapidly in SE, the ratio of benefit to risk seems clearly in favor of treatment.

Though IV valproate appears to be an effective and safe treatment with good tolerability in SE, there is an urgent need for high-quality randomized controlled trials to inform clinicians on the best treatment in SE.

\section{Introduction}

Status epilepticus (SE) can be defined as "a condition characterized by an epileptic seizure that is so frequent or so prolonged as to create a fixed and lasting condition" [1]. In light of the seriousness of the condition and the urge to treat as early as possible to prevent refractory SE, the timeframe has been progressively shortened to a pragmatic definition of $5 \mathrm{~min}$ ongoing seizures [2]. Indeed, if left untreated, SE is potentially fatal or can lead to irreversible brain damage. Population-based studies [3-8] have estimated an incidence of up to 60 cases per 100,000 per year, with the highest incidence in young children and the elderly [9]. Thus, it represents one of the most common neurological emergencies.

There is general agreement that treatment of SE should follow a staged treatment protocol [10]. Randomized controlled trials show that intravenous lorazepam [11-13] or intramuscular midazolam $[14,15]$ are the most efficient treatment in early status. Approximately $30-40 \%$ of all patients fail to respond to initial treatment with benzodiazepines and need further treatment with intravenous antiepileptic drugs (AEDs). A high proportion of these remain refractory, necessitating the use of anesthetics [12, 16-18]. Intravenous phenytoin or phenobarbital is widely used as treatment for established status. However, these drugs are not efficacious in several epilepsy syndromes and there are tolerability issues associated with their use. Both phenobarbital and phenytoin may cause cardiac arrhythmias, hypotension, and respiratory depression, the latter being aggravated by co-administration with benzodiazepines [17].

Intravenous formulations of other AEDs, including valproate, levetiracetam, and lacosamide have generated considerable interest in their potential use for the treatment of established SE after failure of benzodiazepines [19-22]. The first case reports demonstrating the utility of valproate administered rectally for controlling SE go back to the late 1970s [23-26] and continued to be described throughout the 1980s and 1990s [27] until intravenous valproate was introduced [19, 28].

The fact that SE generally occurs without warning, and the need to treat SE as a medical emergency, means that classical randomized clinical trials corresponding to contemporary regulatory standards are extremely challenging to perform. Thus, there are no class I data to support treatment recommendations on the choice of AED for established and refractory SE. Nonetheless, the published literature contains extensive information on the efficacy and safety of intravenous valproate in the treatment of SE, which has been used as the basis for regulatory approval of this treatment in such selected countries as Norway and Germany.

This article provides a systematic literature review of the current evidence for the efficacy and tolerability of valproate in the treatment of SE.

\section{Methods}

A comprehensive review of the literature and searches to find unpublished trials was performed to minimize publication bias. The electronic database MEDLINE (January 1966-19 March 2013; accessed by PubMed) was comprehensively searched. The medical subject heading (MeSH) terms 'valproic acid' and 'status epilepticus', as well as the following free terms were used in multiple search strategies with Boolean operators to find relevant articles published until 19th March 2013: 'valproate', 'valproic acid', and 'status epilepticus'.

The following search strategy was applied: (('valproic acid' [MeSH] OR valpro* OR valproic acid OR valproate) AND ('status epilepticus' [MeSH] OR status epilepticus)).

All resulting titles and abstracts were evaluated, and any relevant article was considered. There were no language restrictions. 
All identified studies were cross referenced to identify any reports that may have been missed. The manufacturer of valproate (Sanofi-Aventis) was asked for any reports of further unpublished studies. For the analysis of efficacy, case reports were excluded, since it is not possible to determine response rates from individual cases. For the same reason, studies in which multiple AEDs were evaluated without presentation of results for individual AEDs were also excluded. Studies using intravenous valproate as first-line treatment or after failure of first-line benzodiazepines (lorazepam or diazepam) were considered eligible. For each study, response rates were extracted as the proportion of patients whose seizures resolved after valproate treatment. Seizure resolution was most frequently adopted in the studies as outcome for efficacy. However, cessation of seizure activity, or AED efficacy, was defined differently by different authors in the selected studies; some were based on termination of seizures alone and others based on a lack of recurrence for a certain period of time. Furthermore, in some studies, seizure resolution was based on clinical signs alone and in other studies on the assessment of electrographic seizure activity.

The frequency of adverse events reported in the studies, particularly hypotension and respiratory depression, was used for the analysis of safety; the worldwide pharmacovigilance database of Sanofi-Aventis was also interrogated to identify reported adverse events.

\section{Results}

\subsection{Studies Identified}

The search strategy yielded 433 results (425 MEDLINE, seven congress abstracts, one unpublished study). After excluding duplicate publications and case reports, 55 articles were provisionally selected. We excluded 25 studies after reading the full published papers; thus, 30 studies contributed to this review: the earliest was published in 1993 and the most recent in 2012.

Overall, we identified through a comprehensive search in MEDLINE 25 publications in which the efficacy of intravenous valproate in SE had been reported [29-53]. Cross-referencing identified seven additional reports in congress abstracts [54-60]. Three of these were redundant $[55,57,60]$ as they corresponded to case series subsequently described in full publications as part of larger cohorts $[35,40,45]$. Finally, the manufacturer of valproate provided the clinical study report of an unpublished study [61].

Of the 30 unique studies identified, six were randomized controlled trials, none of them blinded, comparing intravenous valproate to phenytoin, diazepam, or phenobarbital [41-43, 46, 52, 53], and four non-randomized controlled studies comparing intravenous valproate to phenytoin or levetiracetam [48-51]. One randomized controlled trial also included patients with acute repetitive seizures not entailing the diagnosis of SE. For this study, information from patients with SE was obtained from a systematic review [62]. Of the uncontrolled studies, eight were prospective observational studies and 12 were retrospective case series.

\subsubsection{Randomized Controlled Studies}

Three randomized controlled studies compared intravenous valproate with intravenous phenytoin $[41,42,46]$, two with intravenous diazepam [43, 52], and one with intravenous phenobarbital [53]. These studies included 361 patients (183 were randomized to receive valproate; Table 1; Fig. 1). The phenobarbital study [53] and one diazepam study [43] included only children; one phenytoin study [46] included only adults, whereas the remaining studies [41, 42, 52] included all age groups. The most frequent SE was generalized convulsive. Valproate was administered most often at an initial bolus dose of 20 or $30 \mathrm{mg} / \mathrm{kg}$ (Table 2).

\subsubsection{Non-Randomized Controlled Trials}

Non-randomized controlled studies were included in the present review. Two studies utilized a prospective design $[49,50]$, and two were retrospective [48, 51]. These studies included 455 subjects (197 were randomized to valproate; Table 1).

\subsubsection{Prospective Open-Label Studies}

The eight prospective studies identified are presented in Table 1. Overall, these included 191 patients with SE treated with intravenous valproate (135 adults, 46 children, and ten of unspecified age). These studies all evaluated intravenous valproate administered in monotherapy, usually administered as a bolus $(15-40 \mathrm{mg} / \mathrm{kg}$ ) followed by a maintenance infusion.

\subsubsection{Retrospective Case Series}

We identified 12 retrospective case series (Table 3 ). These included 76 adults, 45 children, and 135 subjects of unspecified age with SE. Again, valproate was usually administered as a bolus $(15-40 \mathrm{mg} / \mathrm{kg}$ ) followed by a maintenance infusion. 
Table 1 Randomized comparative studies evaluating intravenous valproate monotherapy in the treatment of status epilepticus. Studies are listed in decreasing order of sample size. All studies were carried

\begin{tabular}{|c|c|c|c|c|}
\hline References & $N$ & Patients & Type of SE & Dose regimen \\
\hline Agarwal et al. [42] & V: $50, P: 50$ & $\begin{array}{l}62 \text { adults } / 38 \text { children } \\
(<18 \text { y), } 67 \text { male } / \\
33 \text { female }\end{array}$ & $\begin{array}{l}\text { Primary generalized } \\
\text { seizures: } 14 \text {, JME: } \\
2\end{array}$ & $\begin{array}{l}\text { V: Initial bolus } 20 \mathrm{mg} / \mathrm{kg} \text { at } 40 \mathrm{mg} / \mathrm{min} \text {, } \\
\text { P: Initial bolus } 20 \mathrm{mg} / \mathrm{kg} \text { at up to } \\
50 \mathrm{mg} / \mathrm{min}\end{array}$ \\
\hline Misra et al. [41] & V: $35, \mathrm{P}: 33$ & $\begin{array}{l}\text { Adults and children } \\
(1-85 \text { y), } 41 \text { male/ } \\
27 \text { female }\end{array}$ & $\begin{array}{l}\text { Convulsive SE } \\
\text { (unspecified) }\end{array}$ & $\begin{array}{l}\text { V: Initial bolus } 30 \mathrm{mg} / \mathrm{kg} \text { in } 100 \mathrm{ml} \text { over } \\
15 \mathrm{~min} \text {, P: Initial bolus } 18 \mathrm{mg} / \mathrm{kg} \text { in } \\
100 \mathrm{ml} \text { infused at } 50 \mathrm{mg} / \mathrm{min}\end{array}$ \\
\hline Gilad et al. [46] & V: $18, P: 9$ & $\begin{array}{l}\text { Adults }(>18 \text { y), } 19 \\
\text { male/7 female }\end{array}$ & GTC SE & $\begin{array}{l}\mathrm{V} \text { : Initial bolus } 30 \mathrm{mg} / \mathrm{kg} \text { in } 50 \mathrm{ml} \text { of } \\
\text { saline over } 20 \mathrm{~min} \text {, P: Initial bolus of } \\
18 \mathrm{mg} / \mathrm{kg} \text { in } 100 \mathrm{ml} \text { of saline over } \\
20 \mathrm{~min}\end{array}$ \\
\hline Chen et al. [47] & V: 30, D: 36 & $\begin{array}{l}\text { Children and adults } \\
(>15 \mathrm{y}), 36 \text { male/ } \\
30 \text { female }\end{array}$ & GTC and sGTC SE & $\begin{array}{l}\mathrm{V} \text { : Initial bolus } 30 \mathrm{mg} / \mathrm{kg} \text { at } 6 \mathrm{mg} / \mathrm{kg} / \mathrm{min} \\
\text { followed by continuous infusion at } \\
1-2 \mathrm{mg} / \mathrm{kg} / \mathrm{h}, \mathrm{D} \text { : Initial (third) bolus of } \\
0.2 \mathrm{mg} / \mathrm{kg} \text { at } 5 \mathrm{mg} / \mathrm{min} \text { followed by } \\
\text { infusion at } 4 \mathrm{mg} / \mathrm{h} \text { for } 3 \mathrm{~min} \text { and then } \\
\text { increased every } 3 \mathrm{~min} \text { by } 1 \mu \mathrm{g} / \mathrm{min} \text { until } \\
\text { seizure control or maximal duration } \\
(1 \mathrm{~h} \text { ) reached }\end{array}$ \\
\hline Mehta et al. [43] & V: 20, D: 20 & $\begin{array}{l}\text { Children }(\leq 12 \text { y) } \\
\text { (mean } 3.7), 31 \\
\text { boys/9 girls }\end{array}$ & $\begin{array}{l}\text { GTC SE: } 18, \text { sGTC } \\
\text { SE : } 12 \text {, Simple } \\
\text { focal SE: } 8, \\
\text { Multifocal }: 2\end{array}$ & $\begin{array}{l}\text { V: Initial bolus } 30 \mathrm{mg} / \mathrm{kg} \text { over } 2-5 \mathrm{~min} \text {; } \\
\text { if SE uncontrolled, repeat bolus then } \\
\text { infusion at } 5 \mathrm{mg} / \mathrm{kg} / \mathrm{h}, \mathrm{D}: 10 \mu \mathrm{g} / \mathrm{kg} / \mathrm{min} \\
\text { initial infusion increased by } 10 \mu \mathrm{g} / \mathrm{kg} / \mathrm{h} \\
\text { every } 5 \mathrm{~min} \text { if SE uncontrolled up to } \\
100 \mu \mathrm{g} / \mathrm{mg} / \mathrm{kg}\end{array}$ \\
\hline $\begin{array}{l}\text { Malamiri et al. } \\
\text { [53] }\end{array}$ & $\mathrm{V}: 30, \mathrm{~B}: 30$ & $\begin{array}{l}\text { Children }(>2 \text { y) } \\
\text { (median 5, range } \\
3-16), 37 \text { boys/23 } \\
\text { girls }\end{array}$ & $\begin{array}{l}\text { Convulsive SE (all } \\
\text { subtypes) }\end{array}$ & $\begin{array}{l}\mathrm{V} \text { : Initial bolus } 20 \mathrm{mg} / \mathrm{kg} \text { in } 20 \mathrm{ml} \text { saline } \\
\text { at max. } 5-6 \mathrm{mg} / \mathrm{kg} / \mathrm{min} \text { over } 5-10 \mathrm{~min} \text {, } \\
\text { B: Initial bolus } 20 \mathrm{mg} / \mathrm{kg} \text { at max. } \\
60-100 \mathrm{mg} / \mathrm{min}\end{array}$ \\
\hline
\end{tabular}
$B$ phenobarbital, $D$ diazepam, $G T C$ generalized tonic-clonic, JME juvenile myoclonic epilepsy, $P$ phenytoin, $S E$ status epilepticus, $s G T C$ secondary generalized tonic-clonic, $V$ valproate

\subsection{Seizure Outcome}

Response rates are presented in Table 4 . These rates varied across studies, between 35 and $100 \%$ (median $74.35 \%)$. The overall response rate in all studies was $70.9 \% \quad(601 / 848 ; 95 \%$ confidence interval [CI] 67.8-73.9). Outcome in children $(81.3 \% ; 104 / 128$; $95 \%$ CI 74.5-88) was better than in adults (68.5; 207/302; $95 \%$ CI 63.3-73.8). Response rate was lower in controlled non-randomized studies $(61.8 \%, 114 / 185$; $95 \%$ CI 54.6-66.6) than in randomized controlled studies $(75.4 \%$; $138 / 183$; $95 \%$ CI $69.2-81.6)$ or retrospective case series $(68.2 \% ; 197 / 289 ; 95 \%$ CI 62.8-73.8). There was no difference in response rates in convulsive (69.7\%; 246/353; $95 \%$ CI 64.9-74.5) compared with non-convulsive SE $(75 \% ; 15 / 20 ; 95 \%$ CI 56-94), although the comparison is limited by the small number of studies in which outcome was presented according to SE type.

out as single-center open-label trials, except Malamiri et al., which was conducted in two centers

focal SE: 8

Multifocal : 2

Convulsive SE (all 
Fig. 1 Intravenous valproic acid versus intravenous phenytoin, and intravenous valproic acid versus intravenous diazepam. Outcome: seizure cessation after drug administration. Analyses performed using Review Manager 5.2 (available at: http://tech.cochrane.org/ revman/download). $C I$ confidence interval, $D Z P$ diazepam, $I V$ intravenous, $P H T$ phenytoin, $V P A$ valproic acid

\begin{tabular}{|c|c|c|c|c|c|c|c|c|}
\hline \multirow[b]{2}{*}{ Study or Subgroup } & \multicolumn{2}{|c|}{ IV VPA } & \multicolumn{2}{|c|}{ IV PHT } & \multicolumn{3}{|c|}{ Risk Ratio } & \multirow{2}{*}{$\begin{array}{c}\text { Risk Ratio } \\
\text { M-H, Fixed, } 95 \% \mathrm{Cl}\end{array}$} \\
\hline & Events & Total & Events & Total & Weight & M-H, Fixed, 95\% Cl & Year & \\
\hline Misra 2006 & 23 & 35 & 14 & 33 & $21.9 \%$ & $1.55[0.97,2.46]$ & 2006 & \\
\hline Agarwal $200 ?$ & 44 & 50 & 42 & 50 & $63.9 \%$ & $1.05[0.89,1.23]$ & 2007 & \\
\hline Gilad 2008 & 13 & 18 & 7 & 9 & $14.2 \%$ & $0.93[0.59,1.46]$ & 2008 & \\
\hline Total (95\% Cl) & & 103 & & 92 & $100.0 \%$ & $1.14[0.97,1.34]$ & & 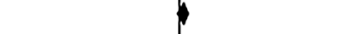 \\
\hline Total events & 80 & & 63 & & & & & \\
\hline \multicolumn{8}{|c|}{$\begin{array}{l}\text { Heterogeneity: } \mathrm{Ch}^{2}=3.57, \mathrm{df}=2(P=0.17) ; \mathrm{I}^{\mathrm{F}}=44 \% \\
\text { Test for overall effect: } Z=1.58(P=0.12)\end{array}$} & $\begin{array}{ccc}0.01 & 0.1 & 1 \\
\text { More in IV PHT } & 10 & 100 \\
\text { More in IV VPA }\end{array}$ \\
\hline & IV VP & & IV DZ & & & Risk Ratio & & Risk Ratio \\
\hline Study or Subgroup & Events & Total & Events & Total & Weight & M-H, Fixed, $95 \% \mathrm{Cl}$ & Year & M-H, Fixed, $95 \% \mathrm{Cl}$ \\
\hline Mehta 2007 & 16 & 20 & 17 & 20 & $48.3 \%$ & $0.94[0.71,1.25]$ & 2007 & 루 \\
\hline Chen 2011 & 15 & 30 & 20 & 36 & $51.7 \%$ & $0.90[0.57,1.43]$ & 2011 & \\
\hline Total $(95 \% \mathrm{Cl})$ & & 50 & & 56 & $100.0 \%$ & $0.92[0.70,1.21]$ & & \\
\hline Total events & 31 & & 37 & & & & & \\
\hline \multicolumn{8}{|c|}{$\begin{array}{l}\text { Heterogeneity: } \mathrm{Chi}^{2}=0.03, \mathrm{df}=1(P=0.86) ; \mathrm{l}^{\mathrm{z}}=0 \% \\
\text { Test for overall effect: } Z=0.60(P=0.55)\end{array}$} & $\begin{array}{l}0.010 .1 \\
\text { More in IV DZP }\end{array}$ \\
\hline
\end{tabular}

Table 2 Non-randomized comparative studies evaluating intravenous valproate monotherapy in the treatment of SE

\begin{tabular}{|c|c|c|c|c|}
\hline References & $N$ & Patients & Type of SE & Dose regimen \\
\hline Tripathi et al. [49] & V: 41, L: 41 & $\begin{array}{l}\text { Adults }(>14 \mathrm{y}), \\
42 \text { male } / 40 \\
\text { female }\end{array}$ & Refractory GTC SE & $\begin{array}{l}\text { V: Initial bolus } 30 \mathrm{mg} / \mathrm{kg} \text { at } 5 \mathrm{mg} / \mathrm{kg} / \mathrm{min} \text {, } \\
\text { L: initial bolus } 30 \mathrm{mg} / \mathrm{kg} \text { at } 5 \mathrm{mg} / \mathrm{kg} / \mathrm{min}\end{array}$ \\
\hline $\begin{array}{l}\text { Tiamkao and } \\
\text { Sawanyawisuth [48] }\end{array}$ & $\mathrm{V}: 32, \mathrm{P}: 37^{\mathrm{a}}$ & $\begin{array}{l}\text { Adults }(>15 \mathrm{y}) \\
\text { No information } \\
\text { on gender }\end{array}$ & GTC SE & $\begin{array}{l}\mathrm{V} \text { : Initial bolus } 15-25 \mathrm{mg} / \mathrm{kg} \text { with } \mathrm{max} \text { infusion } \\
\text { rate of } 50 \mathrm{mg} / \mathrm{min}, \mathrm{P} \text { : Initial bolus } 15-20 \mathrm{mg} / \\
\mathrm{kg} \text { with max infusion rate of } 50 \mathrm{mg} / \mathrm{min}\end{array}$ \\
\hline Kalita et al. [50] & $\mathrm{V}: 65, \mathrm{P}: 52$ & $\begin{array}{l}22 \text { children }(\leq 12 \\
\text { y), } 95 \text { adults, } \\
73 \text { male/44 } \\
\text { female }\end{array}$ & GTC SE: 108, NCSE: 9 & $\begin{array}{l}\text { V: Initial bolus } 30 \mathrm{mg} / \mathrm{kg}, \mathrm{P} \text { : Initial bolus } 20 \mathrm{mg} / \\
\mathrm{kg}\end{array}$ \\
\hline Alvarez et al. [51] & $\begin{array}{l}\text { V: } 59, P: 70 \\
\text { L: } 58\end{array}$ & $\begin{array}{l}\text { Adults }(>16 \mathrm{y}) \text {, } \\
\text { No information } \\
\text { on gender }\end{array}$ & $\begin{array}{l}\text { SE (all subtypes including } \\
\text { NCSE) }\end{array}$ & $\begin{array}{l}\text { V: Initial bolus } 20 \mathrm{mg} / \mathrm{kg} \text { with maintenance } \\
\text { dosage } 1,000-2,500 \mathrm{mg} / \text { day, } \mathrm{P} \text { : Initial bolus } \\
20 \mathrm{mg} / \mathrm{kg} \text { with maintenance dosage } \\
300-400 \mathrm{mg} / \text { day, L: Initial bolus } 20 \mathrm{mg} / \mathrm{kg} \\
\text { with maintenance dosage } 1,000-3,000 / \text { day }\end{array}$ \\
\hline
\end{tabular}

Studies are listed in decreasing order of sample size

a 12 and 20 patients received intravenous valproate as the first- and second-line therapy, respectively

GTC generalized tonic-clonic, $L$ levetiracetam, NCSE non-convulsive status epilepticus, $P$ phenytoin, $S E$ status epilepticus, $V$ valproate

In the second study [46], treatment success was defined as clinical seizure cessation after infusion without need for rescue medication within $20 \mathrm{~min}$ of the infusion. No statistically significant difference in the rate of treatment success was found among patients treated with valproate (13 of $18 ; 72.2 \%)$ and phenytoin (seven of nine patients; $77.8 \%)$. Seizure freedom at $24 \mathrm{~h}$ was obtained in all patients $(100 \%)$ in both groups.

In the study comparing valproate with phenytoin in established SE, treatment success was defined as cessation of all motor and electroencephalography (EEG) seizure activity within $20 \mathrm{~min}$ of starting drug infusion and no return of seizure activity in the following $12 \mathrm{~h}$ [42]. According to this criterion, 44 patients receiving valproate $(88 \%)$ and 42 receiving phenytoin $(84 \%)$ experienced treatment success. Success rates were higher in patients in whom SE had been treated within $2 \mathrm{~h}(p<0.05)$, with only one such patient treated with phenytoin failing to respond.

In the study comparing valproate with diazepam, both in children and in adults, generalized convulsive SE was controlled in $56 \%$ (20 of 36 patients) of the diazepam group and $50 \%$ (15 of 30 patients) in the valproate group [52]. Relapse of SE within $24 \mathrm{~h}$ occurred in $25 \%$ (5 of 20 patients) of the diazepam and $20 \%$ (3 of 15 patients) of the valproate group. Both failed to reach statistical significance, suggesting no differences between groups in terms of efficacy.

A recent systematic review assessing the role of valproate in generalized convulsive SE included the abovementioned studies comparing intravenous valproate with intravenous phenytoin [41, 42, 46] in a meta-analysis [62]. Compared with phenytoin, intravenous valproate had no 
Table 3 Prospective open-label studies evaluating intravenous valproate monotherapy in the treatment of status epilepticus

\begin{tabular}{|c|c|c|c|c|}
\hline References & $N$ & Patients & Type of SE & Dose regimen \\
\hline Olsen et al. [45] & 41 & $\begin{array}{l}\text { Adults }(20-85 \mathrm{y}) \\
18 \mathrm{men} / 23 \text { women }\end{array}$ & $\begin{array}{l}\text { GTC SE: } 19 \\
\text { Complex partial } \\
\text { SE: } 16 \\
\text { Unclassifiable: } 6\end{array}$ & $\begin{array}{l}\text { Initial bolus } 25 \mathrm{mg} / \mathrm{kg} \text { over } 30 \mathrm{~min} \\
\text { Followed by infusion } 100 \mathrm{mg} / \mathrm{h} \text { for } \geq 24 \mathrm{~h} \\
\text { Median bolus dose } 1,800 \mathrm{mg} \text { (range } 700-2,500 \mathrm{mg} \text { ) }\end{array}$ \\
\hline Überall et al. [33] & 41 & $\begin{array}{l}\text { Children }(\leq 16 \text { y) } \\
27 \text { boys/14 girls }\end{array}$ & $\begin{array}{l}\text { GTC SE: } 10 \\
\text { sGTC SE: } 9 \\
\text { Absence status: } 5 \\
\text { Infantile spasms: } 4 \\
\text { Neonatal SE: } 5 \\
\text { EPC: } 2 \\
\text { Complex partial } \\
\text { SE: } 6\end{array}$ & $\begin{array}{l}\text { Initial bolus } 20-40 \mathrm{mg} / \mathrm{kg} \text { over } 1-5 \mathrm{~min} \\
\text { Repeated after } 10-15 \mathrm{~min} \text { if necessary } \\
\text { Then } 5 \mathrm{mg} / \mathrm{kg} / \mathrm{h} \text { infusion }\end{array}$ \\
\hline Giroud et al. [29] & 23 & $\begin{array}{l}\text { Adults }(17-80 \mathrm{y}) \\
13 \mathrm{men} / 10 \text { women }\end{array}$ & $\begin{array}{l}\text { GTC SE: } 8 \\
\text { GMC SE: } 2 \\
\text { PM SE: } 10 \\
\text { PMC SE: } 1 \\
\text { Absence status: } 2\end{array}$ & $\begin{array}{l}\text { Initial bolus } 15 \mathrm{mg} / \mathrm{kg} \\
\text { Followed } 30 \mathrm{~min} \text { later by infusion at } 1 \mathrm{mg} / \mathrm{kg} / \mathrm{h} \\
\text { Mean total dose: } 19.4 \mathrm{mg} / \mathrm{kg}\end{array}$ \\
\hline $\begin{array}{l}\text { Czapiński and } \\
\text { Terczyński [30] }\end{array}$ & 20 & $\begin{array}{l}\text { Adults }(16-76) \\
11 \mathrm{men} / 9 \text { women }\end{array}$ & $\begin{array}{l}\text { Simple partial SE: } \\
11 \\
\text { GTC SE: } 9\end{array}$ & $\begin{array}{l}\text { Initial bolus } 15 \mathrm{mg} / \mathrm{kg} \\
\text { Followed } 30 \mathrm{~min} \text { later by infusion at } 1 \mathrm{mg} / \mathrm{kg} / \mathrm{h} \text { for } 24 \mathrm{~h}\end{array}$ \\
\hline Ramsay et al. [65] & 10 & $\begin{array}{l}\text { Age and gender not } \\
\text { specified }\end{array}$ & Not specified & $\begin{array}{l}\text { Bolus infusion } 20-30 \mathrm{mg} / \mathrm{kg} \text { at } 0.3-0.5 \mathrm{mg} / \mathrm{kg} / \mathrm{min} \\
\text { Total dose up to } 3,000 \mathrm{mg} \text { within } 12 \mathrm{~min}\end{array}$ \\
\hline $\begin{array}{l}\text { Leninger and Hofnagel } \\
\text { [56] }\end{array}$ & 6 & $\begin{array}{l}\text { Adults }(23-70) \\
\text { All women }\end{array}$ & NCSE & $900-3,000 \mathrm{mg} / 24 \mathrm{~h}$ infusion over 2 days \\
\hline $\begin{array}{l}\text { Narayanan and Murthy } \\
{[44]^{\mathrm{a}}}\end{array}$ & $22(2)^{\mathrm{a}}$ & $\begin{array}{l}3 \text { children } / 19 \text { adults } \\
11 \text { male/11 female } \\
\text { ( } 2 \text { adult women })\end{array}$ & $\begin{array}{l}\text { NCSE } \\
(2 \text { absence status })\end{array}$ & Not specified \\
\hline Chen et al. [47] & 48 & $\begin{array}{l}5 \text { children }(<15 \text { y) and } \\
43 \text { adults }(>15 \text { y) } \\
19 \text { male } / 29 \text { female }\end{array}$ & $\begin{array}{l}\text { GTC SE: } 30 \\
\text { sGTC SE: } 14 \\
\text { TSE: } 4\end{array}$ & $\begin{array}{l}\text { Initial bolus of } 15 \mathrm{mg} / \mathrm{kg} \text { over } 5 \mathrm{~min} \text { (repeated } 10-15 \mathrm{~min} \\
\text { later if necessary), followed by continuous infusion at } \\
30 \mathrm{mg} / \mathrm{kg} \text {, infused at an hourly rate of } 6 \mathrm{mg} / \mathrm{kg}\end{array}$ \\
\hline
\end{tabular}

${ }^{a}$ The figures in brackets refer to subjects receiving intravenous valproate monotherapy in studies where more than one AED was studied EPC epilepsia partialis continua, GMC generalized myoclonic, GTC generalized tonic-clonic, NCSE non-convulsive status epilepticus, $P M$ partial motor, $P M C$ partial myoclonic, SE status epilepticus, $S G T C$ secondary generalized tonic-clonic, TSE tonic status epilepticus

statistically significant differences in seizure cessation after drug administration (risk ratio [RR] $1.31,95 \% \mathrm{CI}$ $0.93-1.84)$ and in seizure freedom at $24 \mathrm{~h}(\mathrm{RR} 0.96,95 \%$ CI $0.88-1.06)$.

In the study comparing valproate with diazepam in children, SE was successfully controlled in 16/20 patients receiving valproate $(80 \%)$ and $17 / 20$ patients receiving diazepam $(85 \%)$ [43]. The median time to abrogation of seizure activity was shorter $(p<0.001)$ in the valproate (5 min) than in the diazepam group (17 min). Breakthrough seizures during the maintenance phase occurred in eight patients in each group.

In the study comparing intravenous valproate with intravenous phenobarbital in children, treatment success was defined as cessation of all convulsive activity within 20 min of anticonvulsant infusion [53]. Seizure termination was significantly higher among patients treated with intravenous loading of valproate (27 of 30 patients; $90 \%)$ than in patients treated with phenobarbital (23 of 30 patients; $77 \%)(p=0.189)$. In the phenobarbital group, a statistically significant higher relapse of SE within $24 \mathrm{~h}$ was observed (12 of 23 children) compared with valproate treatment (4 of 27 children).

\subsubsection{Comparative Non-Randomized Studies}

Four studies have compared the efficacy of intravenous valproate with that of intravenous phenytoin or levetiracetam [48-51]. 
Table 4 Retrospective case series evaluating intravenous valproate monotherapy in the treatment of status epilepticus

\begin{tabular}{|c|c|c|c|c|}
\hline References & $N$ & Patients & Type of SE & Dose regimen \\
\hline Limdi et al. [39] & 63 & $\begin{array}{l}\text { Age range not specified } \\
30 \mathrm{men} / 33 \text { women }\end{array}$ & Not specified & $\begin{array}{l}\text { Bolus } 10-78 \mathrm{mg} / \mathrm{kg} \text { until serum levels reach } \\
278 \mathrm{mg} / \mathrm{l}\end{array}$ \\
\hline Czapiński [54] & $120(40)^{\mathrm{a}}$ & $\begin{array}{l}\text { Age and gender not } \\
\text { specified }\end{array}$ & Not specified & $\begin{array}{l}\text { Initial bolus } 15 \mathrm{mg} / \mathrm{kg} \\
\text { Followed by infusion at } 1 \mathrm{mg} / \mathrm{kg} / \mathrm{h}\end{array}$ \\
\hline $\begin{array}{l}\text { Peters and Pohlmann- } \\
\text { Eden [40] }\end{array}$ & 35 & $\begin{array}{l}\text { Adults }(18-85 \text { y) } \\
18 \text { men/17 women }\end{array}$ & $\begin{array}{l}\text { GTC SE: } 6 \\
\text { Simple partial: } 12 \\
\text { Complex partial: } 14 \\
\text { Absence status: } 3\end{array}$ & $\begin{array}{l}\text { Bolus infusion } 4-16 \mathrm{mg} / \mathrm{kg} \text { for } 5-10 \mathrm{~min} \\
\text { Followed by infusion of } 0.5-4 \mathrm{mg} / \mathrm{kg} / \mathrm{h} \text { for } 4 \mathrm{~h} \text { to } \\
6 \text { days }\end{array}$ \\
\hline Naritoku [34] & 32 & $\begin{array}{l}\text { Mean age } 68.5 \text { y } \\
\text { Gender unspecified }\end{array}$ & $\begin{array}{l}\text { GTC SE: } 12 \\
\text { Other: } 20\end{array}$ & $\begin{array}{l}\text { Bolus infusion } 25 \mathrm{mg} / \mathrm{kg} \\
\text { Mean serum concentration } 80.1 \mathrm{mg} / \mathrm{l}\end{array}$ \\
\hline $\begin{array}{l}\text { Rosenow and Knake } \\
\text { [35] }\end{array}$ & 27 & $\begin{array}{l}\text { Adults }(22-94 \text { y) } \\
\text { Gender unspecified }\end{array}$ & $\begin{array}{l}\text { sGTC SE: } 11 \\
\text { Partial SE: } 7 \\
\text { Absence status: } 2\end{array}$ & $\begin{array}{l}\text { Bolus infusion } 300-800 \mathrm{mg} \text { (mean } 1,000 \mathrm{mg} \text { ) } \\
\text { Followed by infusion of } 1,200-1,800 \mathrm{mg} / 24 \mathrm{~h}\end{array}$ \\
\hline Campistol et al. [31] & 19 & $\begin{array}{l}\text { Children }(\leq 7 \text { y) } \\
10 \text { boys } / 9 \text { girls }\end{array}$ & $\begin{array}{l}\text { IG SE: } 4 \\
\text { SP SE: } 2 \\
\text { Other secondary: } 17\end{array}$ & $\begin{array}{l}\text { Initial bolus } 20 \mathrm{mg} / \mathrm{kg} \\
\text { Followed by infusion at } 1 \mathrm{mg} / \mathrm{kg} / \mathrm{h}\end{array}$ \\
\hline Yu et al. [37] & $\begin{array}{l}40 \\
(18)^{\mathrm{a}}\end{array}$ & $\begin{array}{l}\text { Children }(\leq 19 \text { y) } \\
\text { Gender unspecified }\end{array}$ & Not specified & Bolus infusion $25 \mathrm{mg} / \mathrm{kg}$ at $2.8 \mathrm{mg} / \mathrm{kg} / \mathrm{min}$ \\
\hline Katragadda et al. [32] & 12 & 1 child, 11 adults & $\begin{array}{l}\text { Partial NCSE: } 9 \\
\text { Absence status: } 3\end{array}$ & Not specified \\
\hline Price [61] & 11 & $\begin{array}{l}6 \text { children }(6-17 \text { y) } \\
5 \text { adults }(26-72 \text { y) } \\
7 \text { male } / 4 \text { female }\end{array}$ & Not specified & Not standardized \\
\hline Jha et al. [36] & 11 & $\begin{array}{l}2 \text { children }(7,15 \text { y) } \\
9 \text { adults }(24-60 \text { y) } \\
7 \text { male } 4 \text { female }\end{array}$ & $\begin{array}{l}\text { GTC SE: } 1 \\
\text { EPC: } 5 \\
\text { Myoclonic SE: } 4 \\
\text { NCSE: } 1\end{array}$ & $\begin{array}{l}\text { Bolus infusion } 20 \mathrm{mg} / \mathrm{kg} \text { at } 20 \mathrm{mg} / \mathrm{min} \\
\text { Repeated as necessary }\end{array}$ \\
\hline Patel and Jha [38] & 10 & $\begin{array}{l}\text { Adults }(18-60 \mathrm{y}) \\
3 \text { men/7 women }\end{array}$ & $\begin{array}{l}\text { Post-anoxic myoclonic } \\
\text { SE }\end{array}$ & $\begin{array}{l}\text { Bolus infusion } 20 \mathrm{mg} / \mathrm{kg} \text { at } 20 \mathrm{mg} / \mathrm{min} \\
\text { Followed by } 10 \mathrm{mg} / \mathrm{kg} \text { every } 6 \mathrm{~h} \text { for } 24 \mathrm{~h}\end{array}$ \\
\hline Short [59] & $22(7)^{\mathrm{a}}$ & $\begin{array}{l}\text { All ages }(2-75 \mathrm{y}) \\
\text { Mean age } 40 \mathrm{y}\end{array}$ & Not specified & $\begin{array}{l}\text { Mean initial dose: } 1,020 \pm 946 \mathrm{mg} \\
\text { Mean total dose: } 19,017 \pm 30,196 \mathrm{mg} \\
\text { Mean infusion rate: } 21 \pm 13 \mathrm{mg} / \mathrm{min}\end{array}$ \\
\hline
\end{tabular}

${ }^{a}$ The figures in brackets indicate the number of subjects receiving intravenous valproate monotherapy

EPC epilepsia partialis continua, GTC generalized tonic-clonic, $I G$ idiopathic generalized, NCSE non-convulsive status epilepticus, SE status epilepticus, $s G C T$ secondary generalized tonic-clonic, $S P$ simple partial

One prospective study compared intravenous valproate with intravenous levetiracetam in adults with refractory SE at a tertiary center in India [49]. Refractory SE was defined as seizures lasting for more than $1 \mathrm{~h}$, and patients had to have already received intravenous lorazepam and phenytoin. Clinical seizure cessation after infusion was obtained by 26 of 41 patients in the valproate group $(68.3 \%)$ and 28 of 41 patients in the levetiracetam group $(73.2 \%)$, although the difference was not statistically significant. Seizure control was not reached by $13(31.7 \%)$ patients in the valproate group and $11(26.8 \%)$ in the levetiracetam group (difference not statistically significant), and patients required intubation and administration of propofol or midazolam infusion.

One retrospective study was conducted in adults with convulsive SE who were treated with intravenous valproate as first- or second-line AED [48]; 12 (24\%) and 37 (76 \%) patients were treated with intravenous valproate and phenytoin as first-line treatment, respectively. Treatment success was defined as the cessation of seizures by either clinical or EEG evidence. SE ceased in 9 of 12 patients (75\%) with intravenous valproate and 17 of 37 patients (46\%) with intravenous phenytoin as first-line treatment (difference not statistically significant), whereas it ceased 
in 7 of $20(35 \%)$ patients who received second-line valproate.

Kalita et al. [50] conducted a prospective study in children and adults with convulsive and non-convulsive SE, comparing first-line intravenous valproate with firstline intravenous phenytoin. A total of 65 patients received valproate and 52 received phenytoin as a first-line AED, which resulted in control of SE in $56 \%$ of patients with valproate and $44 \%$ of patients with phenytoin. Crossing over of the treatment in uncontrolled patients resulted in seizure cessation in 41 additional patients, whereas 35 $(30 \%)$ remained refractory to both valproate and phenytoin. Within $24 \mathrm{~h}$, seizures recurred in six patients whose SE initially responded to the first or second AED (no further information on valproate or phenytoin was available in the published article).

A retrospective study compared intravenous valproate with phenytoin or levetiracetam as second-line treatment in adults [51]. The primary outcome was the failure of the second-line AED, defined as the need to introduce a further compound to control SE; 15 of 59 patients in the valproate group $(25.4 \%)$ failed to control seizures, compared with 29 of 70 patients in the phenytoin group (41.4\%) and 28 of 58 patients in the levetiracetam group $(48.3 \%)$.

\subsubsection{Status Epilepticus (SE) Subtypes}

Certain studies have reported seizure outcome in response to intravenous valproate treatment in defined seizure types.

3.2.3.1 Generalized Tonic-Clonic SE The largest group of patients for whom seizure outcome has been reported by seizure type corresponds to patients presenting with generalized tonic-clonic SE. Specific outcome was reported in ten studies [29, 30, 33, 34, 36, 40, 45, 47, 49, 52], including a total of 166 patients. Most subjects (119/166) responded to treatment, yielding an overall response rate of $71.7 \%$ (95\% CI 68.3-75.1).

3.2.3.2 Focal SE The other type of SE in which intravenous valproate has been most frequently evaluated is simple or complex focal SE. Overall, data have been reported for 107 patients, included in nine studies [29-31, $33,34,36,45,47,57]$. Most subjects (83/107) responded to treatment, with an overall response rate of $77.6 \%(95 \%$ CI 75.3-79.9).

3.2.3.3 Absence Status Information on the effectiveness of monotherapy with intravenous valproate in absence status is limited. Such patients have been reported in six studies [29, 32, 33, 36, 44, 57]. The number of subjects in these studies was low (16 overall, ranging from one to five patients per study). In all studies except one [57], including three patients in whom absence status was described as atypical, SE was rapidly abrogated by valproate treatment in the majority of cases (12/16 cases). The overall response rate in absence status was $75.0 \%$ (95\% CI 53.8-96.2). In one study, two patients with absence status received valproate as first-line therapy rather than after failure of intravenous benzodiazepines [44]. Both of these patients responded to treatment.

3.2.3.4 Other Presentations of SE Three patients with myoclonic SE were studied by Giroud et al. [29] and four such patients by Jha et al. [36]. One patient in each study failed to respond. The overall success rate was thus $71 \%$. Patel and Jha [38] reported ten patients with post-anoxic myoclonic SE occurring after surgery. SE was abrogated successfully in six of these patients $(60 \%)$ with intravenous valproate given at a dose of 30 (four patients) or 40 (two patients) $\mathrm{mg} / \mathrm{kg}$ within $2-10 \mathrm{~h}$. In addition to these patients, two cases of successful treatment of myoclonic SE have been reported by Sheth and Gidal [63]. Überall et al. [33] reported two cases of status associated with infantile spasms; both responded successfully to intravenous valproate therapy.

\subsubsection{Seizure Outcome and Order of Valproate Administration}

Two randomized [41, 46] and one non-randomized [50] controlled trials used valproate as first-drug antiepileptic treatment instead of benzodiazepines. Four randomized [42, 43, 52, 53] and three non-randomized [48, 49, 51] controlled trials used valproate after failure of first-line benzodiazepines (lorazepam or diazepam).

Among studies using valproate as second-line drug, SE was controlled in 50-90\% of patients allocated to valproate in randomized controlled studies, and in $56 \%$ of patients treated with valproate in the non-randomized controlled trial. Among studies using valproate as first-line drug, SE was controlled in 66-72.2\% of patients allocated to valproate in randomized controlled studies, and in $68.3-75 \%$ of patients treated with valproate in non-randomized controlled trials.

\subsection{Safety}

Information on the safety of intravenous valproate derives from a limited number of dedicated safety studies, adverse event reporting in the efficacy studies described above, individual case reports, and pharmacovigilance reporting. 


\subsubsection{Dedicated Safety Studies}

A number of dedicated studies have investigated the safety of intravenous valproate in patients with epilepsy during the clinical development of this formulation. Not all of these studies concern patients with SE, but the data obtained are nonetheless pertinent to the risk-benefit assessment of intravenous valproate in SE.

The largest of these studies included 318 patients, both children and adults, with epilepsy and hospitalized for seizure-related reasons [64]. The initial dose was $15 \mathrm{mg} /$ $\mathrm{kg} /$ day in four divided doses every $6 \mathrm{~h}$. Subsequent doses were adjusted at the discretion of participating investigators as a function of serum valproate concentrations. The median dose of valproate administered was $375 \mathrm{mg}$ infused over $1 \mathrm{~h}$. The median number of doses was four, given over 2 days. Transient adverse events were reported in 54 patients $(17.5 \%)$, most frequently headache, injection-site reactions, nausea, somnolence, vomiting, dizziness, and taste perversion. None were reported in more than seven patients $(2.3 \%)$. No changes in hematological parameters, blood chemistry, or vital signs were observed.

A second large study compared infusion of valproate at either 1.5 or $3 \mathrm{mg} / \mathrm{kg} / \mathrm{min}$ in 112 hospitalized children or adults with epilepsy [65]. The maximum dose per infusion permitted was $15 \mathrm{mg} / \mathrm{kg}$, and the maximum number of infusions per $24 \mathrm{~h}$ period was four. The primary outcome was changes in blood pressure during and after the first valproate infusion. Although no change in mean blood pressure was observed in the sample as a whole, two subjects infused at a rate of $3 \mathrm{mg} / \mathrm{kg} / \mathrm{min}$ presented transient hypotension. The most common adverse events reported were somnolence, paresthesia, dizziness, and nausea. None of the patients had any alteration of consciousness. A possibly treatment-related case of encephalopathy was reported as a serious adverse event in a patient receiving valproate at an infusion rate of $3 \mathrm{mg} / \mathrm{kg} / \mathrm{min}$ (peak serum valproate concentration of $123 \mu \mathrm{g} / \mathrm{ml}$ ), which resolved upon discontinuation of valproate. No clinically significant abnormalities in blood chemistry or hematology were noted.

A number of other smaller safety studies [66-69] have reported adverse event profiles similar to these two large studies. In addition, one case of asymptomatic hyperammonemia has been described [66]. More recently, a prospective study on 40 patients receiving an intravenous loading dose of $20 \mathrm{mg}$ or $30 \mathrm{mg}$ at $6 \mathrm{mg}$ or $10 \mathrm{mg} / \mathrm{kg} / \mathrm{min}$ of valproate found asymptomatic hyperammonemia in 30 of 40 patients $1 \mathrm{~h}$ after the infusion, decreasing to $66 \%$ at $24 \mathrm{~h}$ after infusion [70]. None of the patients had any alteration of consciousness or increase of transaminases.

Concerning more rapid injection schedules, one study [68] compared blood pressure changes and adverse events between 36 patients infused at a rate of $3 \mathrm{mg} / \mathrm{kg} / \mathrm{min}$ up to a maximum dose of $15 \mathrm{mg} / \mathrm{kg}, 24$ patients infused at $3 \mathrm{mg} / \mathrm{kg} / \mathrm{min}$ up to $30 \mathrm{mg} / \mathrm{kg}$, and six patients infused at $6 \mathrm{mg} / \mathrm{kg} / \mathrm{min}$ up to $15 \mathrm{mg} / \mathrm{kg}$. No increase in the incidence of adverse events was seen with the higher dose or faster infusion rate, and no changes in blood pressure were observed. Subsequently, infusion rates of up to $11 \mathrm{mg} / \mathrm{kg} / \mathrm{min}$ have been reported in pediatric patients, with no untoward safety issue being identified [71].

Since hypotension is a concern with other intravenous AED treatments for SE, such as phenytoin, a retrospective analysis has been performed of the hemodynamic effects of intravenous valproate used to control SE in 13 patients with antecedents of hypotension or cardiovascular instability [72]; 12 of these patients were elderly ( $>64$ years). The mean loading dose of intravenous valproate was $25.1 \pm 5.0 \mathrm{mg} / \mathrm{kg}$ infused at a rate of $36.6 \pm 25.1 \mathrm{mg} / \mathrm{min}$, which produced serum valproate concentrations after completion of the infusion of $78.7 \pm 35.8 \mathrm{mg} / \mathrm{l}$. All except one patient received vasopressors (dopamine or dobutamine) before the valproate infusion began. No significant changes in systolic or diastolic blood pressure were observed during or after valproate infusion, and increases in vasopressor dose were not required. No other cardiovascular adverse effects or changes in cardiac rhythm were observed.

An open-label, prospective trial evaluated the safety of rapid intravenous loading of undiluted valproate $(20$ or $30 \mathrm{mg} / \mathrm{kg} / \mathrm{min}$ at rates of 6 or $10 \mathrm{mg} / \mathrm{kg} / \mathrm{min}$ ) in 40 patients with epilepsy [69]. Rapid administration of valproate was well tolerated, with no significant changes in heart rate and mean arterial pressure by dose group $(20 \mathrm{mg} / \mathrm{kg}$, $30 \mathrm{mg} / \mathrm{kg}$ ) across time (measurements at 20,30, 45, 60, and $240 \mathrm{~min}$ after administration). No patient exhibited alteration of consciousness at 30-60 min after dose administration compared with baseline, although three patients $(7.5 \%)$ complained of sedation and one of nausea. There were no disturbances in cardiac conduction or arrhythmias as indicated by normal electrocardiogram (ECG) in all patients at all time points. A total of 30 patients $(81.5 \%)$ complained of local irritation (pain/ burning or paresthesias) lasting less than 3 min, with no indication of redness, irritation, or phlebitis. No significant changes in platelets or hepatic parameters were observed.

Although this study was not conducted in patients with SE, rapid administration of undiluted valproate proved safe and well tolerated, supporting its use in emergent situations.

The risk of local injection-site reactions with intravenous valproate was explored specifically in a retrospective chart review of two double-blind randomized clinical trials evaluating the use of valproate or phenytoin to prevent post-traumatic seizures in 775 patients with traumatic brain 
injury [73]. Injection-site reactions occurred in $18 \%$ of patients receiving valproate and $25 \%$ of those receiving phenytoin, for the most part during administration of the initial loading dose. When only patients receiving the drugs by a peripheral line were taken into account, the frequency of injection-site reactions with valproate and phenytoin was 21 and $30 \%$, respectively $(p=0.056)$. No cases of skin necrosis or purple glove syndrome were observed in both groups. However, other studies reported an incidence of purple glove syndrome of $1.7-5.9 \%$ after phenytoin administration $[74,75]$.

\subsubsection{Comparative Randomized Studies}

The six comparative randomized studies included 183 patients treated with valproate. The incidence of hypotension and respiratory depression was reported in all six studies, and the incidence of hepatic abnormalities in two studies. The overall rate of these three adverse events in patients treated with intravenous valproate was $0.5,0.5$, and $3.8 \%$, respectively (Table 5). The incidence of hypotension and respiratory depression was lower with valproate than with phenytoin (8.7 and $4.3 \%$, respectively) or diazepam ( 21.4 and $25 \%$, respectively). Conversely, the incidence of hypotension was equal to that of intravenous phenobarbital $(0 \%)$, whereas the incidence of respiratory depression was lower for valproate than that reported for intravenous phenobarbital $(3.3 \%)$. On the other hand, the incidence of liver abnormalities was higher than that reported for intravenous phenytoin $(2.2 \%)$. Given the low patient numbers, none of the differences reported in the individual studies were statistically significant.

A recent systematic review assessing the role of valproate in generalized convulsive SE included the studies comparing intravenous valproate with intravenous phenytoin [41, 42, 46] in a meta-analysis [62]. Compared with phenytoin, intravenous valproate had a statistically lower risk of adverse effects (considered as a whole) (RR 0.31, $95 \%$ CI 0.12-0.85).

\subsubsection{Comparative Not-Randomized Studies}

The four comparative not-randomized studies included 197 patients treated with valproate. The incidence of hypotension and respiratory depression was reported in only one study, showing no difference between the drugs $(0 \%)$ [49].

\subsubsection{Uncontrolled Studies and Case Series}

Adverse events reported in the other prospective studies and retrospective case series discussed above are presented in Table 6. Interpretation of these studies is limited by the disparate nature of adverse event reporting between studies and incomplete ascertainment. Nevertheless, the nature and frequency of the adverse events described are essentially similar to what was observed in the dedicated safety studies. The most frequently reported side effects were nausea/vomiting, dizziness, and sedation (Tables 7 and 8).

No effects on respiratory function were noted. Cardiovascular effects were limited to slight hypotension reported in five patients overall; this was generally mild and transient, and effects of co-medication were suspected in some cases. The local tolerability of intravenous valproate was also good, with only two subjects reporting injection-site pain. Mild hyperammonemia and mild thrombocytopenia were reported in four patients each.

\subsubsection{Case Reports}

A number of case reports have appeared in the literature describing idiosyncratic adverse reactions to intravenous valproate in patients with SE. Several of these have described cases of encephalopathy. For example, Rossetti and Bromfield [76] have described two patients developing acute encephalopathy within $48 \mathrm{~h}$ of receiving intravenous valproate for the treatment of SE. Serum valproate concentrations were in the therapeutic range. In these cases, encephalopathy was associated with hyperammonemia twofold higher than normal. Symptoms resolved after reduction of the valproate dose. Embacher et al. [77] described a woman who developed symptoms of encephalopathy within $24 \mathrm{~h}$ of receiving intravenous valproate. Again, serum valproate levels were not markedly elevated $(29 \mu \mathrm{g} / \mathrm{ml})$, and serum ammonium was within the normal range. The patient recovered completely within $48 \mathrm{~h}$ of discontinuation of valproate. Reversible symptoms of encephalopathy, including confusion or lethargy, were observed in three adult patients with absence SE treated with intravenous valproate and who were on maintenance therapy with lamotrigine [78]. In these patients, the authors related the symptoms to elevated serum levels of lamotrigine due to the well characterized pharmacokinetic interaction between valproate and lamotrigine, whereby valproate inhibits hepatic glucuronidation of lamotrigine.

In addition to these reports of encephalopathy, a case of significant hypotension following intravenous valproate infusion was described in an 11-year-old girl presenting febrile SE following varicella infection and receiving valproate at a dose of $30 \mathrm{mg} / \mathrm{kg}$ over $1 \mathrm{~h}$ [79]. This patient had previously received $10 \mathrm{mg}$ of diazepam and then $1.6 \mathrm{mg}$ of lorazepam, shortly before infusion of valproate was initiated in an attempt to control recurrent seizure activity. The contribution of valproate to the onset of hypotension is consequently difficult to determine.

Intravenous administration of valproate can be associated with acute pancreatitis [106] and with hepatic failure. 
Table 5 Seizure outcome in patients receiving intravenous valproate monotherapy for the treatment of status epilepticus

\begin{tabular}{|c|c|c|c|c|c|}
\hline Study & $\begin{array}{l}\text { Age } \\
\text { group }\end{array}$ & $\begin{array}{l}\text { SE } \\
\text { type }\end{array}$ & Definition of 'responders' & $\begin{array}{l}\text { Responders/ } \\
N^{\mathrm{a}}\end{array}$ & $\%(95 \% \mathrm{CI})$ \\
\hline \multicolumn{6}{|l|}{ Comparative randomized studies } \\
\hline Agarwal et al. [42] & Mixed & CSE & $\begin{array}{l}\text { Clinical or EEG seizure cessation within } 20 \mathrm{~min} \text { of } \\
\text { infusion }\end{array}$ & $44 / 50$ & $88.0(79-97)$ \\
\hline Misra et al. [41] & Mixed & CSE & Clinical seizure cessation after infusion & $23 / 35$ & $65.7(50-81.4)$ \\
\hline Gilad et al. [46] & Adults & CSE & Clinical seizure cessation within 20 min of infusion & $13 / 18$ & $72.2(51.5-92.9)$ \\
\hline Chen et al. [47] & Mixed & CSE & Clinical seizure cessation after infusion & $15 / 30$ & $50.0(32.1-67.9)$ \\
\hline Mehta et al. [43] & Children & CSE & Clinical seizure cessation after infusion & $16 / 20$ & $80.0(62.5-97.5)$ \\
\hline Malamiri et al. [53] & Children & CSE & $\begin{array}{l}\text { Clinical seizure cessation after infusion within } \\
20 \text { min of infusion }\end{array}$ & $27 / 30$ & $90.0(79.3-100)$ \\
\hline \multicolumn{6}{|c|}{ Comparative non-randomized studies } \\
\hline Tripathi et al. [49] & Adults & CSE & Clinical seizure cessation after infusion & $26 / 41$ & $68.3(48.7-78.2)$ \\
\hline $\begin{array}{l}\text { Tiamkao and Sawanyawisuth } \\
\text { [48] }\end{array}$ & Adults & CSE & Clinical seizure cessation within 30 min of infusion & $\begin{array}{l}9 / 12^{\mathrm{b}} \\
7 / 20^{\mathrm{b}}\end{array}$ & $\begin{array}{l}75(50.5-99.5) \\
35(14.1-55.9)\end{array}$ \\
\hline Kalita et al. [50] & Mixed & Mixed & Clinical seizure cessation after infusion & $37 / 65$ & $56.9(44.9-69)$ \\
\hline Alvarez et al. [51] & Adults & Mixed & $\begin{array}{l}\text { No additional AEDs needed for } \geq 48 \mathrm{~h} \text { after clinical } \\
\text { and EEG seizure cessation }\end{array}$ & $44 / 59$ & $74.6(63.5-85.7)$ \\
\hline \multicolumn{6}{|l|}{ Prospective studies } \\
\hline Olsen et al. [45] & Adults & Mixed & Clinical seizure cessation after infusion & $31 / 41$ & $75.6(62.5-88.8)$ \\
\hline Überall et al. [33] & Children & Mixed & Clinical seizure cessation after infusion & $32 / 41$ & $78.0(65.4-90.7)$ \\
\hline Giroud et al. [29] & Adults & Mixed & Clinical seizure cessation within 20 min of infusion & $19 / 23$ & $82.6(67.1-98.1)$ \\
\hline $\begin{array}{l}\text { Czapiński and Terczyński } \\
\text { [30] }\end{array}$ & Adults & CSE & Clinical seizure cessation within $30 \mathrm{~min}$ of infusion & $16 / 20$ & $80.0(62.5-97.5)$ \\
\hline Ramsay et al. [65] & NR & NR & NR & $6 / 10$ & $60.0(26.6-90.4)$ \\
\hline Leninger and Hofnagel [56] & Adults & NCSE & Clinical seizure cessation after infusion & $4 / 6$ & $66.7(28.9-104.4)$ \\
\hline Narayanan and Murthy [44] & Adults & NCSE & Clinical seizure cessation after infusion & $2 / 2$ & 100 \\
\hline Chen et al. [47] & Mixed & CSE & Clinical seizure cessation within $1 \mathrm{~h}$ of the infusion & $42 / 48$ & $87.5(78.1-96.9)$ \\
\hline \multicolumn{6}{|l|}{ Retrospective case series } \\
\hline Limdi et al. [39] & NR & NR & $\begin{array}{l}\text { No additional AEDs needed for } \geq 12 \mathrm{~h} \text { after clinical } \\
\text { and/or EEG seizure cessation }\end{array}$ & $40 / 63$ & $63.3(51.6-75.4)$ \\
\hline Czapiński [54] & NR & NR & Clinical seizure cessation within $30 \mathrm{~min}$ of infusion & $33 / 40$ & $82.5(70.7-94.3)$ \\
\hline $\begin{array}{l}\text { Peters and Pohlmann-Eden } \\
\text { [40] }\end{array}$ & Adults & Mixed & Clinical seizure cessation within 15 min of infusion & $27 / 35$ & $77.1(63.2-91.1)$ \\
\hline Naritoku [34] & NR & CSE & Clinical seizure cessation after infusion & $16 / 32$ & $50.0(32.7-67.3)$ \\
\hline Rosenow and Knake [35] & Adults & Mixed & NR & $12 / 27$ & $44.4(25.7-63.2)$ \\
\hline Campistol et al. [31] & Children & CSE & Clinical seizure cessation after infusion & $11 / 19$ & $57.9(35.7-80.1)$ \\
\hline Yu et al. [37] & Children & Mixed & Clinical seizure cessation within 20 min of infusion & $18 / 18$ & 100 \\
\hline Katragadda et al. [32] & Mixed & NCSE & NR & $9 / 12$ & $75.0(50.5-99.5)$ \\
\hline Price $[61]$ & Mixed & NR & $\mathrm{NR}$ & $10 / 15$ & $66.7(42.8-90.5)$ \\
\hline Jha et al. [36] & Mixed & Mixed & Clinical seizure cessation within $24-48 \mathrm{~h}$ of infusion & $10 / 11$ & $90.9(73.9-107.3)$ \\
\hline Patel and Jha [38] & Adults & CSE & Clinical seizure cessation after infusion & $6 / 10$ & $60.0(29.6-90.4)$ \\
\hline Short [59] & Mixed & NR & NR & $5 / 7$ & $71.4(38-104.9)$ \\
\hline
\end{tabular}

${ }^{a}$ Number of subjects receiving intravenous valproate monotherapy

b 12 and 20 patients received intravenous valproate as the first- and second-line therapy, respectively

$A E D$ anti-epileptic drug, $C I$ confidence interval, $C S E$ convulsive status epilepticus, $E E G$ electroencephalography, NCSE non-convulsive status epilepticus, $N R$ not reported, $S E$ status epilepticus

A case of acute pancreatitis following intravenous valproate administration has been reported, as well as a case of fulminant hepatic failure associated with hemorrhagic shock leading to death in 9-year-old patient with cerebellar syndrome and moderate mental retardation receiving intravenous valproate for the treatment of SE [80]. Four 
Table 6 Adverse event reporting in six comparative randomized studies of valproate in status epilepticus

\begin{tabular}{|c|c|c|c|c|}
\hline Study and adverse event & Valproate & Phenytoin & Diazepam & Phenobarbital \\
\hline \multicolumn{5}{|l|}{ Agarwal et al. [42] } \\
\hline Hypotension & $0 / 50$ & $6 / 50$ & & \\
\hline Respiratory depression & $0 / 50$ & $2 / 50$ & & \\
\hline Mild elevation of liver enzymes & $4 / 50$ & $0 / 50$ & & \\
\hline \multicolumn{5}{|l|}{ Misra et al. [41] } \\
\hline Hypotension & $0 / 35$ & $2 / 33$ & & \\
\hline Respiratory depression & $1 / 35$ & $2 / 33$ & & \\
\hline Liver dysfunction & $3 / 35$ & $2 / 33$ & & \\
\hline \multicolumn{5}{|l|}{ Gilad et al. [46] } \\
\hline Cardiac arrhythmia & $0 / 18$ & $1 / 9$ & & \\
\hline Vertigo & $0 / 18$ & $1 / 9$ & & \\
\hline Hyponatremia & $0 / 18$ & $1 / 9$ & & \\
\hline \multicolumn{5}{|l|}{ Chen et al. [47] } \\
\hline Hypotension & $0 / 30$ & & $2 / 36$ & \\
\hline Respiratory depression & $0 / 30$ & & $2 / 36$ & \\
\hline Liver dysfunction & $0 / 30$ & & $0 / 36$ & \\
\hline Bone marrow suppression & $1 / 30$ & & $0 / 36$ & \\
\hline Hyperammonemia & $4 / 30$ & & $0 / 36$ & \\
\hline \multicolumn{5}{|l|}{ Mehta et al. [43] } \\
\hline Hypotension & $0 / 20$ & & $10 / 20$ & \\
\hline Respiratory depression & $0 / 20$ & & $12 / 20$ & \\
\hline \multicolumn{5}{|l|}{ Malamiri et al. [53] } \\
\hline Hypotension & $1 / 30$ & & & $0 / 30$ \\
\hline Respiratory depression & $0 / 30$ & & & $1 / 30$ \\
\hline Lethargy & $3 / 30$ & & & $17 / 30$ \\
\hline Vomiting & $3 / 30$ & & & $4 / 30$ \\
\hline
\end{tabular}

months after starting valproate treatment (initially as polytherapy up to $600 \mathrm{mg} /$ day and later as monotherapy up to $1,200 \mathrm{mg} /$ day), the child had nausea and vomiting, with subsequent increasing sleepiness and reduced vigilance. Laboratory exams revealed severe liver failure. Post-mortal examinations showed a microvescicular hepatic steatosis with centro- and mediozonal necrosis, hemoperitoneum, retroperitoneal bleeding, and hemorrhage involving pancreas, adrenal glands, and small bowel. The authors did not rule out the presence of underlying metabolic disorders (organic acidemias, mitochondrial disorders, Alper's disease).

\subsubsection{Pharmacovigilance Data}

As of 31 January 2006, a total of 517 medically confirmed adverse drug reactions in 224 patients receiving intravenous valproate had been reported in the worldwide SanofiAventis post-marketing pharmacovigilance database since 1994 [81]. Given the estimated exposure to intravenous valproate over the period ( $>1$ million units prescribed per year worldwide), the reporting rate for adverse events was less than one case per 100,000 administrations. It should be noted that the indication for prescription was not necessarily SE in all these cases, and in many cases the indication was not reported. SE was explicitly reported as the reason for prescription in around one-quarter of these cases. Children, again in all indications, accounted for $21 \%$ of the reported events. The most frequently reported adverse drug reactions (between ten and 50 reports each) were hyperammonemia, coma, encephalopathy, metabolic encephalopathy, thrombocytopenia, confusional state, pancreatitis, hepatic failure, somnolence, and EEG abnormalities. Reporting of these events did not necessarily imply that a causal relationship to treatment had been identified. No relevant differences in the distribution of adverse drug reactions were noted between children and adults or between patients known to have received treatment for SE and the others.

\section{Discussion}

The cumulative literature describes the experiences of over 800 patients with various forms of SE treated with intravenous valproate. The overall response rate to abrogate SE 
Table 7 Adverse event reporting in four comparative non-randomized studies of valproate in status epilepticus

\begin{tabular}{lll}
\hline Study & Adverse event & Patient numbers in the VPA arm \\
\hline Tripathi et al. [49] & Hypotension & $0 / 41$ \\
& Respiratory depression & $0 / 41$ \\
& Liver dysfunction & $0 / 41$ \\
& Thrombocytopenia & $0 / 41$ \\
Tiamkao and Sawanyawisuth [48] & Adverse effects not reported & \\
Kalita et al. [50] & Adverse effects not reported & \\
Alvarez et al. [51] & Adverse effects not reported & \\
\hline
\end{tabular}

Table 8 Adverse event reporting in other clinical studies on valproate in status epilepticus

\begin{tabular}{|c|c|c|}
\hline Study & $\mathrm{N}$ & Main safety findings \\
\hline Campistol et al. [31] & 19 & $\begin{array}{l}\text { No evidence of important side effects; hyperammonemia, somnolence (two } \\
\text { subjects each); thrombocytopenia/lymphopenia (one subject); no hypotension }\end{array}$ \\
\hline Czapiński and Terczyński [30] & 20 & $\begin{array}{l}\text { No adverse events in ten subjects; nausea, injection site pain, abdominal pain } \\
\text { (two subjects each); dizziness, taste perversion, somnolence, tremor (one } \\
\text { subject each) }\end{array}$ \\
\hline Czapiński [54] & 40 & No safety data reported \\
\hline Giroud et al. [29] & 23 & $\begin{array}{l}\text { Moderate, transient decrease in heart rate and blood pressure; no respiratory } \\
\text { changes; no local injection reactions }\end{array}$ \\
\hline Jha et al. [36] & 11 & No adverse events reported; no respiratory depression or hypotension \\
\hline Katragadda et al. [32] & 12 & Thrombocytopenia in three subjects \\
\hline Leninger and Hofnagel [56] & 6 & No safety data reported \\
\hline Limdi et al. [39] & 63 & Hypotension in three subjects; no injection-site reactions \\
\hline Narayanan and Murthy [44] & 2 & Adverse events not reported by treatment group \\
\hline Naritoku [34] & 10 & One case of hyperammonemia; no hypotension \\
\hline Olsen et al. [45] & 41 & One case of moderate hypotension; no other side effects observed \\
\hline Patel and Jha [38] & 10 & No adverse events reported \\
\hline Peters and Pohlmann-Eden [40] & 35 & $\begin{array}{l}\text { No severe side effects; mild side effects in seven subjects (dizziness, skin } \\
\text { reaction, nausea, fatigue, tremor); no hypotension }\end{array}$ \\
\hline Price et al. [61] & 11 & One case of thrombocytopenia \\
\hline Ramsay et al. [65] & 10 & No cardiovascular, hematological, or subjective side effects \\
\hline Rosenow and Knake [35] & 27 & No adverse events reported \\
\hline Short [59] & 7 & Hyperammonemia in one subject; sedation and hypotension in two subjects \\
\hline Überall et al. [33] & 41 & No drug-related systemic or local side effects. No biological changes \\
\hline Yu et al. [37] & 18 & $\begin{array}{l}\text { No significant changes in heart rate or blood pressure; one case of transient } \\
\text { tremor }\end{array}$ \\
\hline Chen et al. [47] & 48 & No evidence for valproate-related systemic or local side effects \\
\hline Tiamkao and Sawanyawisuth [48] & 32 & Adverse effects not systematically reported \\
\hline
\end{tabular}

was $70.9 \%$ (95 \% CI 67.8 to 73.9). This compares favorably to response rates reported in the Veterans Affairs SE Cooperative Study [12], which ranged from $43.6 \%$ for phenytoin to $64.9 \%$ for lorazepam in early SE, and also to the overall response rates of published literature on intravenous levetiracetam, which is around $70 \%$ [19, 20, 82], and lacosamide, which is $56 \%$ in recent series [21, 22, 83]. Response rates to intravenous valproate were better in children than in adults and did not differ between the SE types. In addition, absence seizures, which can be aggravated by phenytoin, responded well to intravenous valproate. The most commonly reported effective doses were between 15 and $45 \mathrm{mg} / \mathrm{kg}$ in bolus $(6 \mathrm{mg} / \mathrm{kg} / \mathrm{min})$ followed by $1-3 \mathrm{mg} / \mathrm{kg} / \mathrm{h}$ infusion, although in the literature higher infusion rates following initial bolus (up to $5 \mathrm{mg} / \mathrm{kg} / \mathrm{h}$ ) have been reported [33]. The response rates were even higher in the randomized controlled trials than in the nonrandomized trials and retrospective as well as prospective open series. This finding is not easy to explain, since usually non-randomized trials tend to overestimate the treatment 
effect [84]. Two other facts may have contributed to this: in a recent meta-epidemiological study on 139 meta-analyses, trials from less developed countries showed more favorable treatment effects than those in developed countries [85]. Three of the six randomized studies using valproate for SE came from India, one from China, and one from Iran, the latter having the highest response rates (90\%). In addition, the etiology, which is recognized as an important predictor of outcome [86, 87], is different from that of the more developed countries, with some of the causes more likely to be easy to control [88-91].

A recent systematic review compared the relative efficacy of five AEDs (valproate, lacosamide, levetiracetam, phenobarbital, phenytoin) in treatment of benzodiazepineresistant convulsive SE [107]. A dichotomous outcome analysis of a single group estimate was performed for each AED with regards to cessation of seizure activity. The efficacy of valproate was higher $(75.7 \%$; $95 \%$ CI 63.7-84.8) than that of other AEDs (lacosamide: analysis not performed due to insufficient data; levetiracetam: $68.5 \%, 95 \%$ CI 56.2-78.7; phenobarbital 73.6\%, $95 \%$ CI 58.3-84.8; phenytoin 50.2\%, $95 \%$ CI 34.2-66.1). Considered overall, cumulative data from the literature are therefore consistent with valproate being a safe and effective therapeutic option for patients with established SE who have previously failed conventional first-line treatment with benzodiazepines. However, it is important to consider that the methodological heterogeneity of the source literature makes the cumulative response rate reported in our review and previous systematic reviews a relatively imprecise result. Limiting the methodological heterogeneity across studies will be of utmost importance in further research in the treatment of SE: investigators should adopt uniform definitions of SE and its different stages, provide individual patient data, and report their results clearly and explicitly [62].

Studies of the safety of intravenous valproate administration in patients with SE showed a low incidence of adverse events overall $(<10 \%)$ mainly dizziness, thrombocytopenia, and mild hypotension), which was independent of infusion rates $[65,67,69,92]$. There were no unexpected side effects compared with the known safety profile of valproate in other indications using oral administration. The low overall incidence of adverse events following infusion, especially the good cardiovascular and respiratory tolerability even in high doses and fast infusion rates up to $30 \mathrm{mg} / \mathrm{kg}$ at $10 \mathrm{mg} / \mathrm{kg} / \mathrm{min}$ [69], of intravenous valproate observed in these studies is all the more noteworthy in that the patients often had multiple morbidities and in some cases had recently received, or were still receiving, other AEDs.

The most serious concern relates to the possibility of acute encephalopathy, sometimes related to hepatic abnormalities or hyperammonemia. This idiosyncratic effect may occur when serum valproate concentrations are in the normal therapeutic range (50-110 $\mu \mathrm{g} / \mathrm{ml})$. However, the number of reported cases is relatively low, and most seem reversible on reduction of the dose of valproate or interruption of treatment. In any case, continued or regular periodic monitoring of the EEG during the stabilization period is desirable for all patients with SE [93], and this can be exploited to detect possible encephalopathy at an early stage. Furthermore, clinicians should monitor lipase, amylase (risk of pancreatitis), ammonium, and transaminase levels. Given the potentially serious or even fatal consequences of not abrogating seizure activity rapidly in $\mathrm{SE}$, the ratio of benefit to risk seems clearly in favor of treatment. Pre-treatment with barbiturates, topiramate, or combinations of both may increase the risk of acute encephalopathy [94-98]. The mechanisms leading to acute encephalopathy are not well understood, but hitherto unrecognized mitochondrial dysfunction may play a crucial role [77, 99]. Thus, valproate should be used with caution in unexplained SE in children.

Intravenous valproate has several other potential advantages for use as a treatment for established SE. Unlike phenytoin and phenobarbital, it does not require organic solvents for dissolution, minimizing the risk of injection-site reactions such as 'purple glove'. Thus, valproate can be injected at a physiological $\mathrm{pH}$ without incompatibility with other commonly used intravenous solutions. The pharmacokinetics of valproate is well characterized [100], and the transition from intravenous to oral therapy can be made smoothly once SE has been controlled and the patient returns to the community [101]. Finally, valproate is a broad-spectrum AED that can be used effectively in virtually all types of epilepsy, and safely in patients whose seizure type is poorly characterized [101, 102]. As such, it would potentially be of particular interest in, for example, absence status, where phenytoin is contraindicated.

Acute treatment of SE is responsible for a high proportion of hospital costs associated with epilepsy. A pharmacoeconomic study conducted in Germany (population 82 million) evaluated that SE causes hospital costs of more than $€ 83$ million each year, around one-quarter of the total of epilepsy-related inpatient treatment costs (€342 million); these costs far exceed those for a newly established diagnosis of epilepsy (€49 million) [108]. Although to date no single study has performed a formal assessment of intravenous valproate treatment versus hospital admission and stay, it is reasonable to hypothesize that prompt seizure control may result in lower economic burden to the healthcare system. However, comparative studies are required to determine which $\mathrm{AED}$ has the more favorable efficacy/safety/cost profile in the treatment of SE. 


\section{Conclusions}

Intravenous valproate appears to be an effective and safe therapeutic option for patients with established SE who have previously failed conventional first-line treatment with benzodiazepines. However, to inform clinical decision making appropriately, a randomized controlled trial comparing the available treatment options in established SE is needed. Starting from the 2nd London Innsbruck Colloquium of Status Epilepticus [103], a trial protocol has been presented and subsequently developed by a group of researchers from the USA and Europe [104, 105]. Once the tribulations of funding this study are overcome, results can be expected in a few years from now.

Conflict of interest No funding was received related to the preparation of this article.

Eugen Trinka has acted as a paid consultant to Eisai, Ever Neuropharma, Biogen Idec, Medtronics, Bial, and UCB and has received speakers' honoraria from Bial, Eisai, GL Pharma, GlaxoSmithKline, Boehringer, Viropharma, Actavis, and UCB Pharma in the past 3 years.

Eugen Trinka has received research funding from UCB Pharma, Biogen-Idec, Red Bull, Merck, the EU, FWF Österreichischer Fond zur Wissenschaftsförderung, and Bundesministerium für Wissenschaft und Forschung. Eugen Trinka is also one of the investigators planning ESETT (Established Status Epilepticus Treatment Trial).

Julia Höfler has received speakers' honoraria from UCB Pharma and travel support from Eisai and GL Pharma.

Alexander Zerbs has no conflict of interest to declare.

Francesco Brigo received speaker's honoraria from UCB Pharma.

Open Access This article is distributed under the terms of the Creative Commons Attribution Noncommercial License which permits any noncommercial use, distribution, and reproduction in any medium, provided the original author(s) and the source are credited.

\section{References}

1. Gastaut H. Clinical and electroencephalographical classification of epileptic seizures. Epilepsia. 1970;11:102-13.

2. Lowenstein DH, Bleck T, Macdonald RL. It's time to revise the definition of status epilepticus. Epilepsia. 1999;40:120-2.

3. Coeytaux A, Jallon P, Galobardes B, Morabia A. Incidence of status epilepticus in French-speaking Switzerland: (EPISTAR). Neurology. 2000;55:693-7.

4. Knake S, Rosenow F, Vescovi M, Oertel WH, Mueller HH, Wirbatz A, et al. Incidence of status epilepticus in adults in Germany: a prospective, population-based study. Epilepsia. 2001;42:714-8.

5. Vignatelli L, Rinaldi R, Galeotti M, de Carolis P, D'Alessandro R. Epidemiology of status epilepticus in a rural area of northern Italy: a 2-year population-based study. Eur J Neurol. 2005;12:897-902.

6. Govoni V, Fallica E, Monetti VC, Guerzoni F, Faggioli R, Casetta $\mathrm{I}$, et al. Incidence of status epilepticus in southern Europe: a population study in the health district of Ferrara, Italy. Eur Neurol. 2008;59:120-6.

7. DeLorenzo RJ, Pellock JM, Towne AR, Boggs JG. Epidemiology of status epilepticus. J Clin Neurophysiol. 1995;12:316-25.
8. Hesdorffer DC, Logroscino G, Cascino G, Annegers JF, Hauser WA. Incidence of status epilepticus in Rochester, Minnesota, 1965-1984. Neurology. 1998;50:735-41.

9. Rosenow F, Hamer HM, Knake S. The epidemiology of convulsive and nonconvulsive status epilepticus. Epilepsia. 2007;48(Suppl 8):S82-4.

10. Shorvon S, Baulac M, Cross H, Trinka E, Walker M. The drug treatment of status epilepticus in Europe: consensus document from a workshop at the first London Colloquium on Status Epilepticus. Epilepsia. 2008;49:1277-85. doi:10.1111/j.15281167.2008.01706_3.x.

11. Leppik IE, Derivan AT, Homan RW, Walker J, Ramsay RE, Patrick B. Double-blind study of lorazepam and diazepam in status epilepticus. JAMA. 1983;249:1452-4.

12. Treiman DM, Meyers PD, Walton NY, Collins JF, Colling C, Rowan AJ, et al. A comparison of four treatments for generalized convulsive status epilepticus. Veterans Affairs Status Epilepticus Cooperative Study Group. N Engl J Med. 1998;339:792-8.

13. Alldredge BK, Gelb AM, Isaacs SM, Corry MD, Allen F, Ulrich $\mathrm{S}$ et al. A comparison of lorazepam, diazepam, and placebo for the treatment of out-of-hospital status epilepticus. N Engl J Med. 2001;345:631-7. Erratum in: N Engl J Med. 2001;345:1860.

14. Silbergleit R, Lowenstein D, Durkalski V, Conwit R, Neurological Emergency Treatment Trials (NETT) Investigators. RAMPART (Rapid Anticonvulsant Medication Prior to Arrival Trial): a double-blind randomized clinical trial of the efficacy of intramuscular midazolam versus intravenous lorazepam in the prehospital treatment of status epilepticus by paramedics. Epilepsia. 2011;52(Suppl 8):S45-7. doi:10.1111/j.1528-1167.2011.03235.x.

15. Silbergleit R, Durkalski V, Lowenstein D, Conwit R, Pancioli A, Palesch Y, NETT Investigators, et al. Intramuscular versus intravenous therapy for prehospital status epilepticus. N Engl J Med. 2012;366:591-600. doi:10.1056/NEJMoa1107494.

16. Mayer SA, Claassen J, Lokin J, Mendelsohn F, Dennis LJ, Fitzsimmons BF. Refractory status epilepticus: frequency, risk factors, and impact on outcome. Arch Neurol. 2002;59:205-10.

17. Trinka E. What is the relative value of the standard anticonvulsants: Phenytoin and fosphenytoin, phenobarbital, valproate, and levetiracetam? Epilepsia. 2009;50(Suppl 12):S40-3. doi:10. 1111/j.1528-1167.2009.02368.x.

18. Novy J, Logroscino G, Rossetti AO. Refractory status epilepticus: a prospective observational study. Epilepsia. 2010;51: 251-6. doi:10.1111/j.1528-1167.2009.02323.x.

19. Trinka E. The use of valproate and new antiepileptic drugs in status epilepticus. Epilepsia. 2007;48:2383.

20. Trinka E. What is the evidence to use new intravenous AEDs in status epilepticus? Epilepsia. 2011;52(Suppl 8):S35-8. doi:10. 1111/j.1528-1167.2011.03232.x.

21. Höfler J, Unterberger I, Dobesberger J, Kuchukhidze G, Walser G, Trinka E. Intravenous lacosamide in status epilepticus and seizure clusters. Epilepsia. 2011;52:e148-52. doi:10.1111/j. 1600-0404.2008.01097.x.

22. Höfler J, Trinka E. Lacosamide as a new treatment option in status epilepticus. Epilepsia. 2013;54:393-404. doi:10.1111/epi. 12058.

23. Barnes SE, Bland D, Cole AP, Evans AR. The use of sodium valproate in a case of status epilepticus. Dev Med Child Neurol. 1976;18:236-8.

24. Vajda FJ, Symington GR, Bladin PF. Rectal valproate in intractable status epilepticus. Lancet. 1977;1:359-60.

25. Vajda FJ, Mihaly GW, Miles JL, Donnan GA, Bladin PF. Rectal administration of sodium valproate in status epilepticus. Neurology. 1978;28:897-9.

26. Viani F, Jussi MI, Germano M, Lotti P, Lotti F. Rectal administration of sodium valproate for neonatal and infantile status epilepticus. Dev Med Child Neurol. 1984;26:678-9. 
27. Holle LM, Gidal BE, Collins DM. Valproate in status epilepticus. Ann Pharmacother. 1995;29:1042-4.

28. Perucca E. Pharmacological and therapeutic properties of valproate: a summary after 35 years of clinical experience. CNS Drugs. 2002;16:695-714.

29. Giroud M, Gras D, Escousse A, Dumas R, Venaud G. Use of injectable valproic acid in status epilepticus. A pilot study. Drug Investig. 1993;5:154-9.

30. Czapiński P, Terczyński A. Intravenous valproic acid administration in status epilepticus. Neurol Neurochir Pol. 1998;32: $11-22$.

31. Campistol J, Fernandez A, Ortega J. Status epilepticus in children. Experience with intravenous valproate. Update of treatment guidelines. Rev Neurol. 1999;29:359-65.

32. Katragadda S, Chand Aluri B, Burdette D. Intravenous administration of valproate for status epilepticus in 12 patients. Epilepsia. 2000;41:216 (Abstract).

33. Überall MA, Trollmann R, Wunsiedler U, Wenzel D. Intravenous valproate in pediatric epilepsy patients with refractory status epilepticus. Neurology. 2000;54:2188-9.

34. Naritoku DK. Outcome of status epilepticus treated with intravenous valproic acid. Adv Stud Med. 2001;1:279-80.

35. Rosenow F, Knake S. Intravenöse Valproinsäuretherapie zur Statusbehandlung. In: Krämer G, Walden J, editors. Valproinsäure. Berlin: Springer; 2002.

36. Jha $\mathrm{S}$, Jose M, Patel R. Intravenous sodium valproate in status epilepticus. Neurol India. 2003;51:421-2.

37. Yu KT, Mills S, Thompson N, Cunanan C. Safety and efficacy of intravenous valproate in pediatric status epilepticus and acute repetitive seizures. Epilepsia. 2003;44:724-6.

38. Patel R, Jha S. Intravenous valproate in post-anoxic myoclonic status epilepticus: a report of ten patients. Neurol India. 2004;52:394-6.

39. Limdi NA, Shimpi AV, Faught E, Gomez CR, Burneo JG. Efficacy of rapid IV administration of valproic acid for status epilepticus. Neurology. 2005;64:353-5.

40. Peters CN, Pohlmann-Eden B. Intravenous valproate as an innovative therapy in seizure emergency situations including status epilepticus-experience in 102 adult patients. Seizure. 2005;14:164-16.

41. Misra UK, Kalita J, Patel R. Sodium valproate vs phenytoin in status epilepticus: a pilot study. Neurology. 2006;67:340-2.

42. Agarwal P, Kumar N, Chandra R, Gupta G, Antony AR, Garg N. Randomized study of intravenous valproate and phenytoin in status epilepticus. Seizure. 2007;16:527-32.

43. Mehta V, Singhi P, Singhi S. Intravenous sodium valproate versus diazepam infusion for the control of refractory status epilepticus in children: a randomized controlled trial. J Child Neurol. 2007;22:1191-7.

44. Narayanan JT, Murthy JM. Nonconvulsive status epilepticus in a neurological intensive care unit: profile in a developing country. Epilepsia. 2007;48:900-6.

45. Olsen KB, Tauboll E, Gjerstad L. Valproate is an effective, well-tolerated drug for treatment of status epilepticus/serial attacks in adults. Acta Neurol Scand Suppl. 2007;187:51-4.

46. Gilad R, Izkovitz N, Dabby R, Rapoport A, Sadeh M, Weller B, et al. Treatment of status epilepticus and acute repetitive seizures with i.v. valproic acid vs phenytoin. Acta Neurol Scand. 2008;118:296-300. doi:10.1111/j.1600-0404.2008.01097.x.

47. Chen L, Feng P, Wang J, Liu L, Zhou D. Intravenous sodium valproate in mainland China for the treatment of diazepam refractory convulsive status epilepticus. J Clin Neurosci. 2009;16:524-6. doi:10.1016/j.jocn.2008.06.007.

48. Tiamkao S, Sawanyawisuth K. Predictors and prognosis of status epilepticus treated with intravenous sodium valproate. Epileptic Disord. 2009;11:228-31. doi:10.1684/epd.2009.0271.
49. Tripathi M, Vibha D, Choudhary N, Prasad K, Srivastava MV, Bhatia R, et al. Management of refractory status epilepticus at a tertiary care centre in a developing country. Seizure. 2010;19:109-11. doi:10.1016/j.seizure.2009.11.007.

50. Kalita J, Nair PP, Misra UK. A clinical, radiological and outcome study of status epilepticus from India. J Neurol. 2010;257: 224-9. doi:10.1007/s00415-009-5298-9.

51. Alvarez V, Januel JM, Burnand B, Rossetti AO. Second-line status epilepticus treatment: comparison of phenytoin, valproate, and levetiracetam. Epilepsia. 2011;52:1292-6. doi:10.1111/j. 1528-1167.2011.03056.x.

52. Chen WB, Gao R, Su YY, Zhao JW, Zhang YZ, Wang L, Ren $\mathrm{Y}$, et al. Valproate versus diazepam for generalized convulsive status epilepticus: a pilot study. Eur J Neurol. 2011;18:1391-6. doi:10.1111/j.1468-1331.2011.03420.x.

53. Malamiri RA, Ghaempanah M, Khosroshahi N, Nikkhah A, Bavarian B, Ashrafi MR. Efficacy and safety of intravenous sodium valproate versus phenobarbital in controlling convulsive status epilepticus and acute prolonged convulsive seizures in children: a randomised trial. Eur J Paediatr Neurol. 2012;16: 536-41. doi:10.1016/j.ejpn.2012.01.012.

54. Czapiński P. Retrospective analysis of therapeutic efficacy of various modalities in status epilepticus. Epilepsia. 1998;39:32 (Abstract).

55. Knake S, Vescovi M, Hamer H, Wirbatz A, Rosenow F. Intravenous sodium valproate in the treatment of status epilepticus. Epilepsia. 1999,40:150 (Abstract).

56. Leninger T, Hofnagel A. Nonconvulsive status epilepticus treated with intravenous valproate. Epilepsia. 1999;40:149 (Abstract).

57. Peters C, Pohlman-Eden B. Efficacy and safety of intravenous valproate in status epilepticus. Epilepsia. 1999;40:149-50 (Abstract).

58. Ramsay R, Lowe M, DeToledo J, Cilavizza N, Pryor F. Pharmakokinetics and safety of high dose rapid infusion of IV valproate (Depacon). Neurology. 1999;A523 (Abstract).

59. Short D. Depacon administartion, safety and efficacy in a hospital setting. Epilepsia. 1999;40:226 (Abstract).

60. Olsen K, Tauboll E, Gjerstad L. Intravenous valproate (VPA) is effective in status epilepticus/serial attacks in adults. Epilepsia. 2004;45:260 (Abstract).

61. Price D. Sodium valproate intravenous: report on clinical experience in neurology and neurosurgery. Paris: Sanofi-Aventis; 1986.

62. Brigo F, Storti M, Del Felice A, Fiaschi A, Bongiovanni LG. IV Valproate in generalized convulsive status epilepticus: a systematic review. Eur J Neurol. 2012;19:1180-91. doi:10.1111/j. 1468-1331.2011.03606.x.

63. Sheth RD, Gidal BE. Intravenous valproic acid for myoclonic status epilepticus. Neurology. 2000;54:1201.

64. Devinsky O, Leppik I, Willmore LJ, Pellock JM, Dean C, Gates J, et al. Safety of intravenous valproate. Ann Neurol. 1995;38: $670-4$.

65. Ramsay RE, Cantrell D, Collins SD, Walch JK, Naritoku DK, Cloyd JC, et al. Safety and tolerance of rapidly infused Depacon. A randomized trial in subjects with epilepsy. Epilepsy Res. 2003;52:189-201.

66. Naritoku DK, Mueed S. Intravenous loading of valproate for epilepsy. Clin Neuropharmacol. 1999;22:102-6.

67. Venkataraman V, Wheless JW. Safety of rapid intravenous infusion of valproate loading doses in epilepsy patients. Epilepsy Res. 1999;35:147-53.

68. Wheless JW, Vazquez BR, Kanner AM, Ramsay RE, Morton L, Pellock JM. Rapid infusion with valproate sodium is well tolerated in patients with epilepsy. Neurology. 2004;63:1507-8.

69. Limdi NA, Knowlton RK, Cofield SS, Ver Hoef LW, Paige AL, Dutta S, Faught E. Safety of rapid intravenous loading of valproate. Epilepsia. 2007;48:478-83. 
70. DeWolfe JL, Knowlton RC, Beasley MT, Cofield S, Faught E, Limdi NA. Hyperammonemia following intravenous valproate loading. Epilepsy Res. 2009;85:65-71. doi:10.1016/j.eplepsyres. 2009.02.012.

71. Morton LD, O'Hara KA, Coots BP, Pellock JM. Safety of rapid intravenous valproate infusion in pediatric patients. Pediatr Neurol. 2007;36:81-3.

72. Sinha S, Naritoku DK. Intravenous valproate is well tolerated in unstable patients with status epilepticus. Neurology. 2000;55: $722-4$.

73. Anderson GD, Lin Y, Temkin NR, Fischer JH, Winn HR. Incidence of intravenous site reactions in neurotrauma patients receiving valproate or phenytoin. Ann Pharmacother. 2000;34: 697-702.

74. O'Brien TJ, Cascino GD, So EL, Hanna DR. Incidence and clinical consequence of the purple glove syndrome in patients receiving intravenous phenytoin. Neurology. 1998;51:1034-9.

75. Burneo JG, Anandan JV, Barkley GL. A prospective study of the incidence of the purple glove syndrome. Epilepsia. 2001;42: 1156-9.

76. Rossetti AO, Bromfield EB. Efficacy of rapid IV administration of valproic acid for status epilepticus. Neurology 2005;65:500501; author reply 500-501.

77. Embacher N, Karner E, Wanschitz J, Beer R, Trinka E. Acute encephalopathy after intravenous administration of valproate in non-convulsive status epilepticus. Eur J Neurol. 2006;13:e5-6.

78. Burneo JG, Limdi N, Kuzniecky RI, Knowlton RC, Mendez M, Lawn N, et al. Neurotoxicity following addition of intravenous valproate to lamotrigine therapy. Neurology. 2003;60:1991-2.

79. White JR, Santos CS. Intravenous valproate associated with significant hypotension in the treatment of status epilepticus. J Child Neurol. 1999;14:822-3.

80. Fernandez-Fernandez FJ, Garcia-Rego J, Garcia-Jimenez A, Sesma P. Hemorrhagic shock and fulminant hepatic failure associated with valproate. An Med Interna. 1995;12:606-8.

81. Larch J, Trinka E. Intravenous valproate-a systematic review of the evidence. Epilepsia. 2006;47(s3):38-9 (Abstract).

82. Trinka E, Dobesberger J. New treatment options in status epilepticus: a critical review on intravenous levetiracetam. Ther Adv Neurol Disord. 2009;2:79-91. doi:10.1177/1756285608100460.

83. Kellinghaus C, Berning S, Immisch I, Larch J, Rosenow F, Rossetti AO, et al. Intravenous lacosamide for treatment of status epilepticus. Acta Neurol Scand. 2011;123:137-41. doi:10. 1111/j.1600-0404.2010.01423.x.

84. Ioannidis JP, Haidich AB, Pappa M, Pantazis N, Kokori SI, Tektonidou MG, Contopoulos-Ioannidis DG, Lau J. Comparison of evidence of treatment effects in randomized and nonrandomized studies. JAMA. 2001;286:821-30.

85. Panagiotou OA, Contopoulos-Ioannidis DG, Ioannidis JP. Comparative effect sizes in randomised trials from less developed and more developed countries: meta-epidemiological assessment. BMJ. 2013;346:f707.

86. Tan RY, Neligan A, Shorvon SD. The uncommon causes of status epilepticus: a systematic review. Epilepsy Res. 2010;91: 111-22. doi:10.1016/j.eplepsyres.2010.07.015.

87. Trinka E, Höfler J, Zerbs A. Causes of status epilepticus. Epilepsia. 2012;53(Suppl 4):S127-38. doi:10.1111/j.1528-1167. 2012.03622.x.

88. Misra UK, Kalita J, Nair PP. Status epilepticus in central nervous system infections: an experience from a developing country. Am J Med. 2008;121:618-23.
89. Bharucha NE, Raven RH, Nambiar VK. Review of seizures and status epilepticus in HIV and tuberculosis with preliminary view of Bombay hospital experience. Epilepsia. 2009;50(Suppl 12):S64-6. doi:10.1111/j.1528-1167.2009.02347.x.

90. Singh G. Other central nervous system infections and status epilepticus. Epilepsia. 2009;50(Suppl 12):67-9. doi:10.1111/j. 1528-1167.2009.02360.x.

91. Newton CR. Status epilepticus in resource-poor countries. Epilepsia. 2009;50(Suppl 12):S54-5. doi:10.1111/j.1528-1167. 2009.02364.x.

92. Limdi NA, Faught E. The safety of rapid valproic acid infusion. Epilepsia. 2000;41:1342-5.

93. Shorvon S. The management of status epilepticus. J Neurol Neurosurg Psychiatry. 2001;70(Suppl 2):II22-27.

94. Hamer HM, Knake S, Schomburg U, Rosenow F. Valproateinduced hyperammonemic encephalopathy in the presence of topiramate. Neurology. 2000;54:230-2.

95. Vivekanandan S, Nayak SD. Valproate-induced hyperammonemic encephalopathy enhanced by topiramate and phenobarbitone: a case report and an update. Ann Indian Acad Neurol. 2010;13:145-7. doi:10.4103/0972-2327.64638.

96. Chakor RT, Bharote HS. Topiramate-valproate-induced encephalopathy in migraine. Headache. 2012;52:1321-2. doi:10. 1111/j.1526-4610.2012.02213.x.

97. Noh Y, Kim DW, Chu K, Lee ST, Jung KH, Moon HJ, Lee SK. Topiramate increases the risk of valproic acid-induced encephalopathy. Epilepsia. 2013;54:e1-4. doi:10.1111/j.1528-1167. 2012.03532.x.

98. Blackford MG, Do ST, Enlow TC, Reed MD. Valproic Acid and topiramate induced hyperammonemic encephalopathy in a patient with normal serum carnitine. J Pediatr Pharmacol Ther. 2013;18:128-36. doi:10.5863/1551-6776-18.2.128.

99. Dhamija R, Gavrilova RH, Wirrell EC. Valproate-induced worsening of seizures: clue to underlying diagnosis. J Child Neurol. 2011;26:1319-21. doi:10.1177/0883073811402204.

100. Bialer M. Clinical pharmacology of parenteral use of antiepileptic drugs. Epilepsia. 2007;48(Suppl 8):S46-8.

101. Aldenkamp A, Vigevano F, Arzimanoglou A, Covanis A. Role of valproate across the ages. Treatment of epilepsy in children. Acta Neurol Scand Suppl. 2006;184:1-13.

102. Ben-Menachem E, Schmitz B, Tomson T, Vajda F. Role of valproate across the ages. Treatment of epilepsy in adults. Acta Neurol Scand Suppl. 2006;184:14-27.

103. Trinka E, Shorvon S. The proceedings of the Innsbruck Colloquium on Status Epilepticus. Epilepsia. 2009;50(Suppl 12):S1-2. doi:10.1111/j.1528-1167.2009.02357.x.

104. Cock HR, ESETT Group. Established status epilepticus treatment trial (ESETT). Epilepsia. 2011;52(Suppl 8):S50-2. doi:10. 1111/j.1528-1167.2011.03237.x.

105. Bleck T, Cock H, Chamberlain J, Cloyd J, Connor J, Elm J, Fountain N, et al. The established status epilepticus trial 2013. Epilepsia. 2013;54(Suppl 6):89-92. doi:10.1111/epi.12288.

106. Grosse P, Rüsch L, Schmitz B. Pancreatitis complicating treatment with intravenous valproic acid. J Neurol. 2002;249:484-5.

107. Yasiry Z, Shorvon SD. The relative effectiveness of five antiepileptic drugs in treatment of benzodiazepine-resistant convulsive status epilepticus: a meta-analysis of published studies. Seizure. 2014;23:167-74.

108. Strzelczyk A, Knake S, Oertel WH, Rosenow F, Hamer HM. Inpatient treatment costs of status epilepticus in adults in Germany. Seizure. 2013;22:882-5. 